\title{
B cell clonal expansion is correlated with antigen-specificity in young but not old mice
}

Andreas Agrafiotis ${ }^{1,2}$, Daniel Neumeier ${ }^{1}$, Kai-Lin Hong1, Tasnia Chowdhury ${ }^{3}$, Roy Ehling ${ }^{1}$, Raphael Kuhn ${ }^{1}$, loana Sandu $^{2}$, Victor Kreiner ${ }^{1}$, Dale Starkie ${ }^{3}$, Daniel J. Lightwood ${ }^{3}$, Annette Oxenius ${ }^{2}$, Sai T. Reddy ${ }^{1, \#, ~ A l e x a n d e r}$ Yermanos ${ }^{1,2,4, \#}$

${ }^{1}$ Department of Biosystems Science and Engineering, ETH Zurich, Basel, Switzerland

${ }^{2}$ Institute of Microbiology, ETH Zurich, Zurich, Switzerland

${ }^{3}$ UCB Pharma, Berkshire, United Kingdom

${ }^{4}$ Department of Pathology and Immunology, University of Geneva, Geneva, Switzerland

"Correspondence: sai.reddy@ethz.ch ; ayermanos@gmail.com

\section{Abstract}

Aging of the humoral immune response has been shown to affect its critical role in defending the host from a variety of pathogens. Technical limitations have nevertheless made it challenging to investigate the relationship between genotype and phenotype of antibody repertoires in the context of aging. We therefore performed single-cell sequencing of over 95,000 B cells to simultaneously investigate B cell receptor $(B C R)$ repertoires and gene expression profiles in the bone marrow and spleens of young and old mice following immunizations with a protein antigen. We discovered the presence of clonally expanded B cells in both young and old mice, which had distinct transcriptional phenotypes and exhibited age-associated gene signatures relating to plasma cell differentiation and protein folding and stabilization genes. Recombinant expression of 227 monoclonal antibodies revealed that clonally expanded B cells were frequently antigen-specific in young mice but not in old mice. Furthermore, we detected clonal convergence across different mice which was correlated with antigen-specificity. Although isotype- and expansion-specific transcriptional phenotypes could be detected, there was little correlation with antigen-specificity and transcriptional signatures. Together, our work provides an age-resolved single-cell repertoire resource that further relates antibody specificity, repertoire features, and whole transcriptomes.

\section{Introduction}

Age-related changes in the structure and function of the immune system, collectively termed immunosenescence, have been shown to adversely affect the humoral immune response in the context of infection, vaccination and autoimmunity (Gibson et al., 2009; Goodwin et al., 2006; Leng and Goldstein, 2010; Weinberger et al., 2008; Weksler, 2000). Additionally, the downregulation of activation-induced cytidine deaminase (AID), the principal regulator of class-switch recombination (CSR) and somatic hypermutation (SHM), in combination with lower levels of the transcription factor E47, has been linked to a decrease in CSR and reduced number and size of germinal centres (GCs) the aged individuals (Frasca, 2018; Henry et al., 2019; Oh et al., 2019; Put et al., 2004). Other effects of aging target metabolic pathways such as mitochondrial energy production and one-carbon metabolism (Kurupati et al., 2019). Immunosenescence has also been linked with a higher production of autoantibodies (Rubtsov et al., 2011; Watad et al., 2017), and may reflect a pathologic process whereby homeostatic pathways related to cell clearance, antigen-receptor signaling, or cell effector 
Agrafiotis et al. 2

functions are disturbed (Elkon and Casali, 2008). Finally, aging has been implicated in an altered antibody repertoire, exemplified by a decline in B lymphopoiesis (Eren et al., 1988; Johnson and Cambier, 2004; Johnson et al., 2002; Kline et al., 1999; Rossi et al., 2005; Stephan et al., 1996), reduced numbers of naive B cells (Ongrádi and Kövesdi, 2011; Siegrist and Aspinall, 2009), and increase of age-associated B cells (ABCs) (Birjandi et al., 2011; Hao et al., 2011; Rodriguez-Zhurbenko et al., 2019). Despite these reported changes to the aged immune repertoire, the relationship between clonal selection and accompanying antibody specificity remains mostly uncharacterized.

Recent advances in single-cell sequencing (scSeq) technologies have made it possible to obtain both transcriptome and antibody (B cell receptor, $B C R$ ) repertoire information from single $B$ cells at highthroughput (Croote et al., 2018; Horns et al., 2020; Saikia et al., 2019; Singh et al., 2019), thereby enabling an integrated analysis of genotypic (i.e., antibody sequence) and phenotypic (e.g., specificity, affinity, epitope) metrics of antibody repertoires. For instance, it was recently demonstrated that the majority of memory B cells elicited by influenza vaccination produced antibodies that did not bind the immunogen in young subjects (Horns et al., 2020). Similarly, in the context of chronic viral infection, highly expanded and class-switched (IgG) plasma cells produced antibodies specific for multiple viral antigens (Neumeier et al., 2021a). In addition, integration of single-cell transcriptome data with antibody specificity suggested a correlation between transcriptional profile and viral antigen specificity.

Here, we perform single-cell sequencing of $\sim 100,000$ B cells to simultaneously relate antibody repertoires, gene expression profiles, and antibody specificities in the bone marrow (BM) and spleens of young and old mice following immunizations with a model antigen [human tumor necrosis factor receptor 2 (TNFR2)] (Fischer et al., 2020; Medler and Wajant, 2019). We observed the presence of clonally expanded B cells in both young and old mice, which had distinct transcriptional phenotypes and exhibited age-associated gene signatures relating to plasma cell differentiation, protein folding and stabilization genes. Furthermore, our bioinformatic analysis revealed an increased incidence of clones present in spleens and BM of individual animals, in addition to clonal convergence across different mice, both of which correlated with TNFR2-specificity. Finally, we recombinantly expressed 227 monoclonal antibodies from BM and spleen repertoires, which confirmed that clonally expanded $B$ cells often produced immunogen-specific antibodies in immunized young mice but not in old mice.

\section{Results}

\section{Clonal expansion is detected in young and old mice following immunization}

To profile B cell selection following serial protein immunizations, we immunized a cohort of 3-monthold $(3 \mathrm{~m})$ male C57BL6 mice $(n=5)$ with five successive injections of $10 \mu \mathrm{g}$ of the extracellular domain of human TNFR2 mixed with $20 \mu \mathrm{g}$ of the adjuvant monophosphoryl lipid A (MPLA). Our previous findings suggested that clonal expansion in the bone marrow plasma cell repertoire was correlated to antigen-specificity when immunizing with the model protein ovalbumin (Neumeier et al., 2021b). For this study, we selected an antigen that has potentially reduced immunogenicity given its high sequence similarity ( $61.3 \%)$ to the murine homologue of TNFR2. As aging has been linked to the increased production of autoantibodies and dysregulation of immune tolerance (Elkon and Casali, 
Agrafiotis et al. 3

2008; Ginaldi et al., 2001; Ratliff et al., 2013), we additionally performed the same immunization schemes with additional cohorts of 12-month-old $(12 \mathrm{~m})(\mathrm{n}=3)$ and 18-month-old $(18 \mathrm{~m})$ male mice $(n=3)$. We isolated BM PCs (CD138 $\left.{ }^{\text {hi }}, \mathrm{TACl}^{\text {hi }}\right)$ and B cells from the spleen (CD19 $\left.{ }^{\text {hi }}, \operatorname{lgM}^{\text {low }}, \lg ^{\text {low }}\right)$ and performed single-cell antibody repertoire sequencing using the 10x genomics 5' immune profiling pipeline (Figure 1A). Following library preparation, deep sequencing, and alignment to reference VDJ genes, we recovered a total of $\sim 650,00$ cells containing exactly one heavy chain and one light chain, with an average of 3,200 cells per mouse. The majority of cells were of the lgM isotype for both spleen and BM (Figure 1B). After grouping cells that shared identical CDRH3+CDRL3 amino acid sequences (hereafter referred to as clone), we observed only hundreds of unique clones for each mouse or organ repertoire, despite higher numbers of cells (Figure 1C), thereby suggesting the presence of clonal expansion. Further investigation revealed that the majority of the BM PC repertoires demonstrated extensive clonal expansion, with approximately $75 \%$ of clones supported by more than one cell (Figures 1D, S1, S2). On the other hand, we observed that the majority of splenic B cell clones were only supported by a single cell barcode, which was comparable across all three age groups (Figures 1D, S1, S2). Having observed that the majority of cells were of the $\lg M$ isotype for all age groups in $\mathrm{BM}$ and spleen, we next determined whether this was consistent with the most expanded clones for each repertoire. While the majority of expanded clones for BM PCs were IgM, the most expanded clones were predominantly IgG in the spleen repertoires (Figures 1E, S3, S4). Nevertheless, clonal expansion for IgM, IgG, and IgA isotypes was present in both organs (Figures S5, S6, S7). Previous single-cell antibody repertoire sequencing studies suggest a strong correlation between classswitched clones and the number of contemporary amino acid sequence variants existing within an individual clone (Neumeier et al., 2021a, 2021b). Here, we observed that the number of cells for the most expanded IgG and IgA clones demonstrated a minor correlation with the number of amino acid variants, whereas some IgM clones contained a considerable number of amino acid variants (Figure 1F).

\section{Clonal convergence allows the identification of antigen-specific sequences}

We next questioned whether identical immunization schemes with TNFR2 resulted in convergent antibody responses across mice in $\mathrm{BM}$ and spleen repertoires. We first quantified the number of public clones (identical CDRH3+CDRL3 amino acid sequences) found across multiple mice (in either BM or spleen of an individual mouse) by calculating the Jaccard index, which is defined as the intersection divided by the union of CDR3 sequences. This pairwise analysis revealed a low number of public clones across mice and no clear pattern was observed between age groups (Figure 2A). In some cases, public clones could be detected in multiple mice (Figure 2B); these highly shared public clones were also correlated with high expansion levels (Figure 2C). As the overall fraction of public clones was low (less than $2 \%$ of clones shared on average), we questioned whether this was consistent for both BM and spleen repertoires. Quantifying the number of identical clones found between samples revealed the existence of identical clones across mice, which was largely driven by overlap in the BM repertoires (Figures 2D, 2E). In addition, we observed that within each mouse, these organ overlapping clones exhibited higher levels of clonal expansion when compared to clones observed in only one organ (Figure 2F). 
Agrafiotis et al. 4

We next determined whether organ-overlapping or public clones exhibited binding specificity towards the immunogen. We restricted our validation to clones with the majority of cells expressing lgG (Neumeier et al., 2021b) and recombinantly expressed and validated the specificity for the 12 most expanded (ranked by normalized expansion per mouse) organ-overlapping IgG clones from each age cohort (Parola et al., 2019; Pogson et al., 2016). We additionally included four clones that were both organ-overlapping and public (found in more than one mouse) to evaluate the relationship between the emergence of class-switched public clones and binding specificity. For each clone, the antibody variant (combined $\mathrm{VH}+\mathrm{VL}$ nucleotide sequence) supported by the most unique cell barcodes was expressed (Table S1). Enzyme-linked immunosorbent assays (ELISA) were performed and antigenbinding was determined on the basis of 3-fold above background. This revealed that approximately $30 \%(10 / 34)$ and 50\% (2/4) of antibodies originating from the organ-overlapping clones and public clones exhibited antigen-specificity, respectively, which was similar for all age groups (Figure 2G). Furthermore, specificity and clonal expansion were not correlated for either the BM or the spleen for the tested clones found in both organs (Figure $2 \mathrm{H}$ ). Taken together, these findings support previously proposed models in which public clones can be used to support identification of antigen-specific sequences (Csepregi et al., 2021; Jackson et al., 2014; Trück et al., 2015).

\section{Clonal expansion correlates with antigen specificity in young but not old mice.}

Since age-associated differences were observed related to clonal expansion, we next determined how this correlated with antigen-specific binding. To this end we recombinantly expressed the most expanded lgG clones from repertoires across all age groups and screened them for binding to TNFR2 by ELISA (total 225 unique IgGs) (Figure 3). Surprisingly, we observed that in young mice, there was a considerably higher fraction of antigen-binding clones compared to older mice (Figure 3). This was most apparent in BM PC repertoires, where approximately 31.3\% of clones tested (30 out of 96) from young mice exhibited TNFR2 specificity, in contrast to only6.2\% (4 out of 64) in older mice (Figure 3A). In the spleen we detected a similar trend of $20.7 \%$ (6 out of 29 ) and $14.2 \%$ (3 out of 21) binders for young and old mice, respectively (Figure 3B). Furthermore, independent of age and organ, we observed that higher degrees of clonal expansion was not correlated with antigen-specificity, as antigen-binding and non-binding clones were distributed throughout the most expanded clones of each repertoire.

\section{Antigen-specific clones display convergent immune repertoire features}

We next questioned whether repertoire features could differentiate between antigen-binding and nonbinding clones. We initially quantified the mean number of somatic hypermutations (SHMs) per clone in the full-length $\mathrm{VH}$ and $\mathrm{VL}$ regions, which surprisingly showed that the antigen-binding fraction of clones exhibited lower levels of SHM (Figure 4A). Despite previous studies demonstrating a correlation between the number of unique amino acid variants and the number of cell barcodes, we observed no such relationship between antigen-binding and non-binding clones (Figures 4B, S8C). Next, we visualized the distribution of $\lg G$ subtypes (IgG1, IgG1B, IgG2C, IgG3) and observed a higher percentage of lgG1 sequences among the antigen-binding fraction of clones (Figures 4C, S8A). The presence of IgG1 sequences among the antigen-binding clones was even more pronounced both on the clonal and cellular level when using a more stringent definition of binder and non-binder (>10-fold 
Agrafiotis et al. 5

and <2-fold relative to background ELISA signal, respectively) (Figure S8B). We further determined if certain $\mathrm{VH}-\mathrm{VL}$ germline combinations were enriched in the antigen-binding or non-binding fraction of the tested clones. Circos plots of the 64 experimentally verified antigen-binding and 201 non-binding clones did not show enrichment for certain germline combinations in either of the two groups (Figure 4D). The same observation was made when looking at other germline features, such as the JH-JL gene usage (Figure S8D).

To investigate whether clonal convergence could be detected within the binding fraction of antigenbinding clones, we constructed sequence similarity networks based on the edit distance of CDRs (Miho et al., 2018). Antigen-binding clones demonstrated clustering across a range of edit distances (Figures 4E, S8E). Some of these antigen-binding clusters contained clones utilizing different germline genes despite similar CDR3s, potentially suggesting convergent sequence motifs (Figures 4F, S8F). However, visualizing the amino acid sequences for the most frequent CDRH3 and CDRL3 lengths revealed little indication of amino acid or biochemical bias between antigen-binding and non-binding sequences (Figures 4G, S8G).

\section{Single-cell sequencing reveals organ, expansion and isotype transcriptional heterogeneity}

After having extensively profiled antibody repertoires, we next leveraged the inherent capabilities of scSeq to integrate transcriptional information with antibody repertoire features such as clonal expansion and clonal overlap. To this end, we performed unsupervised clustering and uniform manifold approximation projection (UMAP), which gave rise to 14 distinct cell clusters based on global gene expression (Figures 5A, S9). Closer examination of the transcriptional space allowed us to distinguish between clusters populated principally by BM- and spleen-derived cells, or clusters with cells originating from both organs at similar ratios (Figure 5B, 5C, S10). Furthermore, using characteristic B cell genes, we observed distinct expression patterns between B cells from either organ, in addition to heterogeneous expression of markers such as Sell, Ccr7, Sdc1, Slamf7, Xbp1 and S/pi (Figures 5D, S11).

We next determined if separating BM and spleen repertoires would reveal any age-associated transcriptional changes between young and old mice. In contrast to the unambiguously distinct transcriptional profiles exhibited between the B cells of the BM and those of the spleen (Figures 5B, $\mathrm{S10}$ ), only minor variations were detected within the different age cohorts of the same organ (Figure S12). However, looking at the cluster membership across the different mice revealed a decrease of the fraction of cells found in clusters 1 and 6 , and an increase in cluster 3 with age (Figure 5C). Based on the transcriptional profiles of these clusters, we observed an upregulation of Apoe, which plays a pivotal role in lipid metabolism (Rasmussen et al., 2019) and is involved in B cell lipid antigen presentation (Allan et al., 2009). Additionally, Ccr6, which plays a role in GC reactions (Reimer et al., 2017; Wiede et al., 2013), was upregulated in cluster 3, whereas Vpreb3, which is implicated in B cell maturation (Rodig et al., 2010; Rosnet et al., 2004), was downregulated (clusters 3 and 6). We additionally restricted our analysis to just the $3 \mathrm{~m}$ and $18 \mathrm{~m}$ cohorts and quantified differential gene expression separately for each organ (Figure S13). Interestingly, we observed for both organs a downregulation in young mice of $A C 133103.1$, an uncharacterised gene marker, and an upregulation 
Agrafiotis et al. 6

of Eif3f which has been implicated in regulation of translation and cell growth with its expression significantly decreased in many human cancers (Marchione et al., 2013; Shi et al., 2006).

Previous work suggested isotype-specific gene expression signatures in BM PCs following viral infection (Neumeier et al., 2021a). Overlaying isotype information onto the UMAP revealed separation of IgG-, IgM-, and IgA-expressing cells (Figure 5F). Performing differential gene expression analysis revealed exclusive genes defining IgG (ApoE, Gimap4), IgA (Ccr10, Glpr1) and IgM (Ggh, S/c3a2) isotypes, some of which were consistent with previous findings (Neumeier et al., 2021a). We next asked whether expanded B cell clones (clones supported by more than one cell) were transcriptionally distinct compared to those clones where clonal expansion was not detected (clones supported by only one single cell). This comparison between expanded and unexpanded cells resulted in 21 genes differentially regulated in the BM and 225 in the spleen (p.adj < 0.01) (Figure 5E). Expanded spleen cells expressed high levels of genes associated with plasma cell differentiation and survival such as Xbp1 (Shaffer et al., 2004; Todd et al., 2009), Mzb1 (Andreani et al., 2018), and Zbtb20 (Chevrier et al., 2014; Corcoran and Nutt, 2016). They also exhibited low levels of Vpreb3, Fcer2a, which inhibits B cell growth and differentiation (Yodoi et al., 1989), and Ebf1, which is associated with maintenance of $B$ cell identity (Nechanitzky et al., 2013). The identification of cluster defining genes in the BM was less obvious, however, we did observe a downregulation of Vpreb3 in the expanded cells, as seen in the spleen (Figure S14).

\section{BM PC transcriptional signatures in organ overlapping clones}

As we previously uncovered antigen-binding in the organ overlapping clones, we next investigated whether this repertoire feature was associated with distinct transcriptional properties. Splenic B cells also found in the BM of a given mouse exhibited a distinctive transcriptional signature compared to cells present only in the spleen (Figure 6A). Moreover, we noticed that these organ-overlapping cells upregulated and downregulated genes such as Xbp1, Mzb1, Apoe, Ebf1, Fcer2a or Vpreb3 in the same manner as the expanded splenic B cells. Furthermore, we observed that all the top upregulated genes (based on expression) in these shared cells were also highly expressed in the BM cohorts compared to the spleen, and all the downregulated genes also showed lower expression in the BM (Figures 6B, S15). Collectively, these findings demonstrate the existence of a highly expanded B cell subpopulation within the spleen microenvironment that shares common CDR3 amino acid sequences with B cells from the BM and exhibits transcriptional similarities to BM PCs.

\section{Antigen-binding and non-binding clones occupy similar transcriptional states}

Having observed comparable repertoire features between antigen-binding and non-binding clones, we investigated whether distinct gene expression profiles could be detected between these populations. Differential gene expression did not reveal any consistent markers across the two organs (Figures 6C, S16A). Furthermore, visualizing individual clones on the UMAP indicated that antigenbinding did not dictate location or transcriptional cluster membership (Figures 6DC, 6ED). Similar genes associated with antigen-binding were also detected when using a more stringent threshold (>10x ELISA signal above background) (Figures S16B, S16C). 


\section{Discussion}

Agrafiotis et al. 7

Here, we used single-cell antibody repertoire and transcriptome sequencing to investigate how B cell clonal selection signatures vary with age. Our scSeq approach allowed us to relate individual transcriptomes to the antibody repertoire for nearly one hundred thousand B cells, thereby providing unprecedented insight into the relationship between gene expression and clonal selection. We observed comparable levels of clonal expansion in repertoires from both young and aged mice following successive immunization with human TNFR2. In addition, we observed class-switched antibodies among the most expanded clones in both spleen and BM repertoires.

The emergence of novel scSeq workflows has made it possible to comprehensively test and reconstruct the specificity of antibodies based on their immune repertoire profiles. Using antibody expression and screening, we were thus able to demonstrate that a fraction of expanded cells in the repertoires of young mice produced antibodies with specificity to TNFR2 following immunization. This fraction was comparable to our previous results in the context of immunization with ovalbumin, where approximately $45 \%$ of the most expanded clones were found to be antigen-binding (Neumeier et al., 2021b). Moreover, our results demonstrate the presence of expanded B cells lacking antigen-binding, suggesting either the occurrence of bystander expansion of $B$ cells following vaccination as previously described (Horns et al., 2020; Wrammert et al., 2008) or that immunization-induced clonal expansion fails to exceed levels present in naive repertoires. The percentage of antigen-binding clones, however, was greatly reduced in older mice despite comparable repertoire features such as germline gene usage and clonal expansion. This decrease of antigen-binding in aged mice may be linked to previous reports that naive $B$ cell repertoires have restricted clonal diversity in aged individuals or that IgM+ B cells accumulate in the bone marrow during aging, thereby reducing available space for newly recruited B cells (Gibson et al., 2009; Mehr and Melamed, 2011; Miller and Allman, 2003). Other parameters linking immune senescence to a decreased number of antigen-specific plasma cells could involve altered of pro-B/pre-B proliferative capacities (Min et al., 2006; Shahaf et al., 2006), a decline of number and size of germinal centers (Zheng et al., 1997), and deficiency relating to class-switching (Frasca et al., 2004). Further measuring of affinities and, in the case of antiviral immunizations, neutralization potential, would be beneficial to assess the impact of aging on the quality of the antibody response. In addition, we saw that antigen specificity was largely stochastic and could not be predicted based on the clonal rank of expanded cells in both young and old mice, which is in accordance with previous results (Neumeier et al., 2021b).

We could integrate single-cell transcriptomes with antibody repertoires, which revealed that antigenbinding $\mathrm{B}$ cells had distinct immune repertoire features but similar transcriptional profiles to nonbinding sequences. More specifically, our data suggested that antigen-binding clones were less mutated in the $\mathrm{V}$ - and J-regions and preferentially expressed the IgG1 subtype. We expected that immunization would lead to clear transcriptional differences relating to recent selection between antigen-binding and non-binding B cells. Surprisingly, we observed minor transcriptional differences between these two populations of cells when performing unsupervised clustering and differential gene expression analysis. Transcriptional differences were however observed in IgM-, IgA- and IgG- 
Agrafiotis et al. 8

expressing B cells, which was consistent with previous results (Neumeier et al., 2021a), as well as expansion-specific transcriptional clustering (Kuhn et al., 2021; Yermanos et al., 2021a).

Single-cell antibody repertoire sequencing has provided an unprecedented molecular quantification of clonal selection. Thus far, the majority of repertoire studies conducted have examined lymphocytes following immunogenic stimuli such as infection or immunization using model proteins (Bailey et al., 2017; Burton and Hangartner, 2016; Cao et al., 2020; Goldstein et al., 2019; Kräutler et al., 2020; Turner et al., 2020; Wen et al., 2020). In contrast, there is limited information regarding the behavior of humoral immunity triggered by a molecule with host-sequence similarity. Our results have implications for the discovery of therapeutic monoclonal antibodies, such as TNFR2-specific antibodies have demonstrated potential in clinical applications spanning both pro- and anti-inflammatory conditions (Fischer et al., 2020; Medler and Wajant, 2019). Together, our findings here suggest the reduced potential of immunogen-specific plasma cells to undergo clonal expansion in aged individuals and further provides a resource of nearly one-hundred thousand B cells for the larger immunological community to study the relationship between clonal selection and antigen specificity.

\section{Methods}

\section{Mouse experiments}

All animal experiments were performed in accordance with institutional guidelines and Swiss federal regulations. Experiments were approved by the veterinary office of the canton of Basel-Stadt (animal experimentation permission 2582). 3-, 12- and 18-month-old C57BL/6 male (Janvier) mice were repeatedly immunized every 14 days (5 times) subcutaneously (s.c.) into the flank with $10 \mu \mathrm{g}$ of human

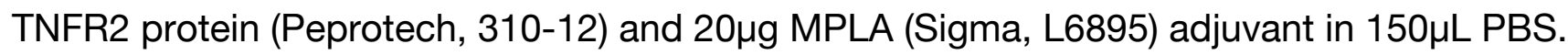

\section{Isolation of bone marrow plasma cells and splenic B cells}

A single cell suspension was prepared by flushing the bone marrow from the hind legs in RPMI containing 10\% FCS buffer with $10 \mathrm{ng} / \mathrm{mL}$ IL6 (Peprotech, 216-16). A red blood cell lysis step was performed in $2 \mathrm{~mL}$ ammonium-chloride-potassium (ACK) lysis buffer for 1 minute at room temperature and subsequently inactivated with $20 \mathrm{~mL}$ RPMI containing 10\% FCS. Single-cell suspensions were stained with the following antibodies in FACS buffer (1:200 dilution) CD138-APC, CD4-APC-Cy7, CD8a-APC-Cy7, NK1.1-APCCy7, Ter119-APC-Cy7, TACI-PE, B220-APC, CD19-PE-Cy7 for 30 minutes at $4^{\circ} \mathrm{C}$. Cell sorting was performed using a FACSAria with FACSDiva software into RPMI.

\section{Single-cell sequencing of antibody repertoires}

Single-cell sequencing libraries were constructed from the isolated bone marrow plasma cells following the demonstrated 10x Genomics' protocol: 'Direct target enrichment - Chromium Single Cell V(D)J Reagent Kits' (CG000166). Briefly, single cells were co-encapsulated with gel beads (10x Genomics, 1000006) in droplets using 5 lanes of one Chromium Single Cell A Chip (10x Genomics, 1000009) with a target loading of 13,000 cells per reaction. V(D)J library construction was carried out using the Chromium Single Cell 5' Library Kit (10x Genomics, 1000006) and the Chromium Single Cell V(D)J Enrichment Kit, Mouse B Cell (10x Genomics, 1000072) according to the manufacturer's 
Agrafiotis et al. 9

instructions. Final libraries were pooled and sequenced on the Illumina NextSeq 500 platform (mid output, 300 cycles, paired-end reads) using an input concentration of 1.8 pM with 5\% PhiX.

\section{Repertoire analysis}

Raw sequencing files arising from Illumina sequencing lanes were supplied as input to the command line program cellranger (v3.1.0) on a high-performance cluster. Raw reads were aligned to the germline segments from the GRCm38 reference (vdj_GRCm38_alts_ensembl-3.1.0) and subsequently assigned into clonal families based on identical combinations of CDRH3+CDRL3 nucleotide sequence via cellranger. Further filtering was performed to include only those cells containing exactly one heavy chain and one light chain sequence. Firstly, clonotypes containing identical CDR3 amino acid sequences were merged into the same clonal family. Clonal frequency was determined by counting the number of distinct cell barcodes for each unique CDR3. Those cells in clones supported by only one cell were considered unexpanded clones, whereas those clones supported by two or more cells were considered expanded. Clone variants were determined as those sequences with the exact same $\mathrm{VH}$ and VL. SHMs were determined as nucleotide substitutions in the V and J regions. Clonal overlap was calculated based on identical amino acid CDRH3+CDRL3 sequences between any two or more repertoires. Germline gene usage was determined by cellranger's vdj alignment to the murine reference. $\mathrm{V}$ and $\mathrm{J}$ gene combinations were calculated and visualized with circos plots using the VDJ_circos function in Platypus (v2.1) (Yermanos et al., 2021b) with a label.threshold of 2 or 5. Isotype was determined based on the constant region alignment per cell or for the majority of cells within each clonal family. In the case that the variable region alignment was provided but the isotype was not recovered, the isotype was labeled as "Unknown". Jaccard indices were calculated by quantifying the intersection between two groups divided by the length of the union of the same groups. Similarity networks were calculated based on the VDJ_network function in Platypus (v2.1), which first calculates the edit distance separately for HC and LC CDR3s, and then draws edges between those clones with a distance below the specified threshold.

\section{Transcriptome analysis}

The output matrices, barcodes, and features files from cellranger (10x Genomics) for each sample were supplied as input to Seurat (v4.0) (Satija et al., 2015) using the Read10X function and subsequently converted into a Seurat object using the function "CreateSeuratObject". Only those cells containing less than $20 \%$ of mitochondrial reads were retained in the analysis. All BCR related genes (V(D)J genes, isotype constant regions, J-chain) were filtered out prior to further analyses. Data was normalized using a scaling factor of 10000 and variable features were found using 2000 genes. Cluster resolution was set to 0.5 and the first fifteen PCR dimensions (determined via visualization of the normalized Seurat object using an elbow plot) were used for neighborhood detection. UMAP was performed again using the first fifteen PCA dimensions. All repertoires were proceeded and filtered together. Genes defining clusters were determined by setting the min.pct argument equal to 0.25 using Seurat's "FindMarkers" function. For analyses involving B cells found in repertoire sequencing data, only those cells containing identical nucleotide barcodes sequences were included and reanalyzed in the Seurat object. Heatmaps of cluster defining genes were selected for the top genes ranked by logFC after employing the Bonferroni correction for multiple hypothesis testing (p.adj < 0.01). 


\section{Antibody expression and validation}

Antibodies were either transiently expressed in HEK 293 Expi cells using the ExpiFectamine 293 Transfection Kit (Thermo, A14524) and the pFUSE2ss vector system (Invitrogen) as previously described (Vazquez-Lombardi et al., 2018) or as stable hybridoma cell lines using CRISPR/Cas9 genome editing as before (Parola et al., 2019). Specificity was validated by performing normalized supernatant ELISAs against the extracellular domain of human TNFR2 (Peprotech, 310-12 and inhouse production). Flow cytometry phenotyping of hybridoma cells was performed on a BD FACS Aria III. Typically, $5 \times 10$ cells were stained for 30 minutes on ice in $50 \mu \mathrm{l}$ of a labeling mix consisting of antiIgG2C-AlexaFluor488 (Jackson ImmunoResearch, 115-545-208) and anti-IgK-Brilliant Violet421 (BioLegend, cat\# 409511) at 1:100 and 1:50 dilutions, respectively. Before acquiring, cells were washed twice. For ELISA experiments, $0.2 \mu \mathrm{m}$ sterile-filtered cell culture supernatant of a $6 \mathrm{~d}$ culture was used to confirm TNFR2-specificity. ELISA plates were coated with the capturing reagent (TNFR2 or control) in PBS at $4 \mu \mathrm{g} / \mathrm{ml}$, blocked with PBS supplemented with $2 \%(\mathrm{w} / \mathrm{v}$ ) milk (AppliChem, A0830) and incubated with cell culture supernatant. The supernatant from an influenza- (PDB 5GJT) and OVAspecific hybridoma served as negative controls (Neumeier et al., 2021b). A commercial antibody against human TNFR2 was used as a positive control (Invitrogen, AHR3022). An anti-mouse IgG-HRP (Sigma, A2554) was employed at 1:1500 and used for detection. Binding was quantified using the 1Step Ultra TMB-ELISA substrate solution (Thermo, 34028) and $1 \mathrm{M} \mathrm{H}_{2} \mathrm{SO}_{4}$ for reaction termination. Absorbance at $450 \mathrm{~nm}$ was recorded on an Infinite 200 PRO (Tecan). All commercial antibodies were used according to manufacturer's recommendations. For each clone tested, the antibody variant (combined $\mathrm{VH}+\mathrm{VL}$ nucleotide sequence) supported by the most unique cell barcodes was selected to be expressed. Clones were considered to bind to TNFR2 when the ELISA signal measured was at least three times higher than that of a negative background control unless otherwise specified.

\section{Hybridoma cell culture}

Hybridoma cell lines were cultivated in high-glucose DMEM Medium (Thermo, 61965-026), supplemented with $10 \%$ (v/v) of ultra-low IgG FBS (Thermo, 16250078), $100 \mathrm{U} / \mathrm{ml}$ Pen/Strep (Thermo, 15140-122), $10 \mathrm{mM} \mathrm{HEPES} \mathrm{(Thermo,} \mathrm{15630-056)} \mathrm{and} 50 \mu \mathrm{M}$ 2-mercaptoethanol (Thermo, 31350-010). Cell lines were maintained at $37^{\circ} \mathrm{C}, 5 \% \mathrm{CO} 2$ and passaged every 72 hours.

\section{Data visualization}

Heatmaps depicting clonal overlap were created using the Rpackage pheatmap (v1.0.12). Heatmaps displaying differential gene expression were produced using the DoHeatmap function in the $R$ package Seurat (v4.0) (Butler et al., 2018). Volcano plots and gene enrichment plots were ggplot (v3.3.5) (Wickham and Wickham, 2007). Similarity networks were produced using the R package igraph (v1.2.6) (Csardi et al., 2006). Sequence logo plots were generated using the R package ggseqlogo2 (v0.1) (Wagih, 2017). Experimental overview (Figure 1A) was created using BioRender.com. All other plots were produced using Prism v9 (Graphpad). All error bars indicate the standard error of mean.

Acknowledgements: We acknowledge and thank Dr. Christian Beisel, Elodie Burcklen, and Ina Nissen at the ETH Zurich D-BSSE Genomics Facility Basel for support and assistance. We also thank 
bioRxiv preprint doi: https://doi.org/10.1101/2021.11.09.467876; this version posted November 11,2021 . The copyright holder for this preprint (which was not certified by peer review) is the author/funder, who has granted bioRxiv a license to display the preprint in perpetuity. It is made available under aCC-BY-ND 4.0 International license.

Agrafiotis et al. 11

the D-BSSE FACS facility for experimental support. Funding: This work was supported by the European Research Council Starting Grant 679403 (to STR), ETH Zurich Research Grants (to STR and AO), and an ETH Seed Grant (AY). Competing Interests: There are no competing interests. 

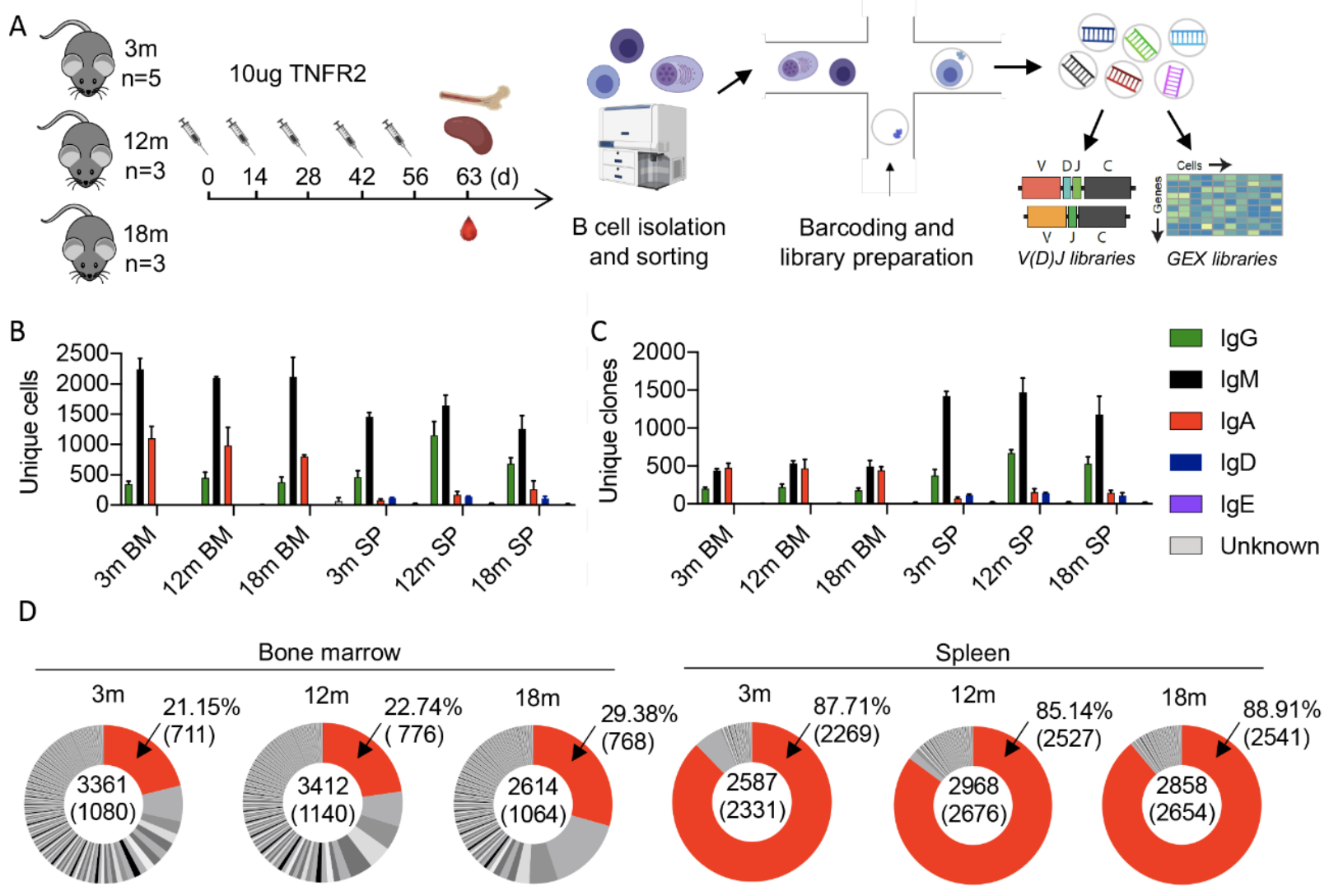

E

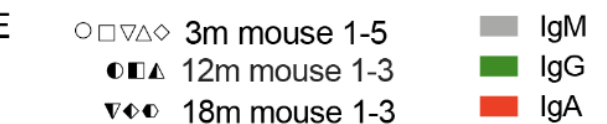

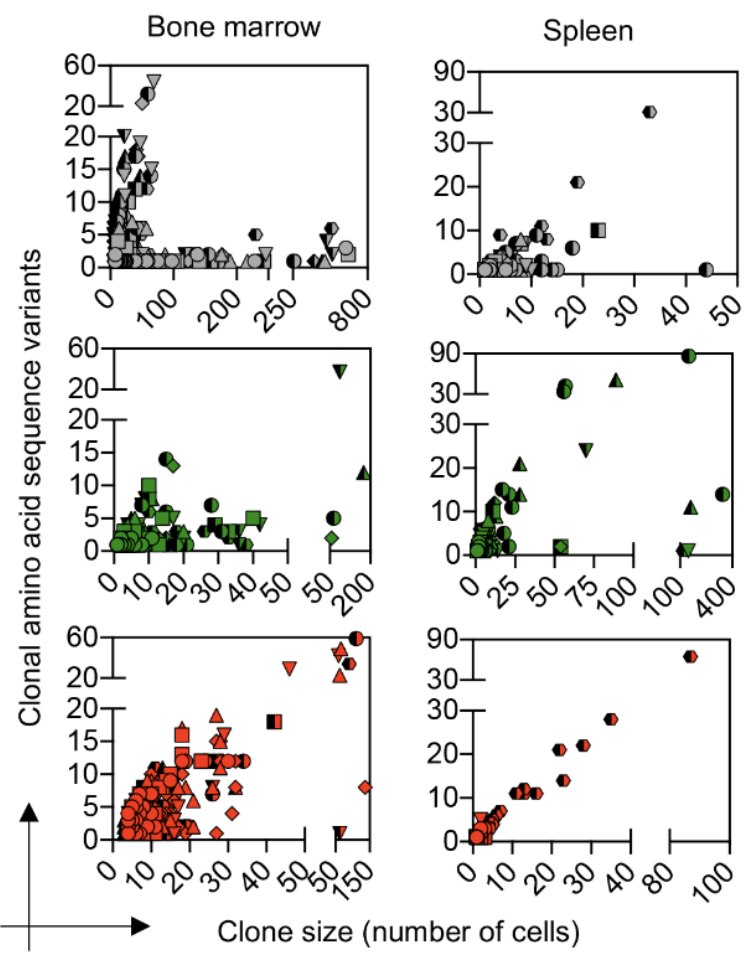

$\mathrm{F}$
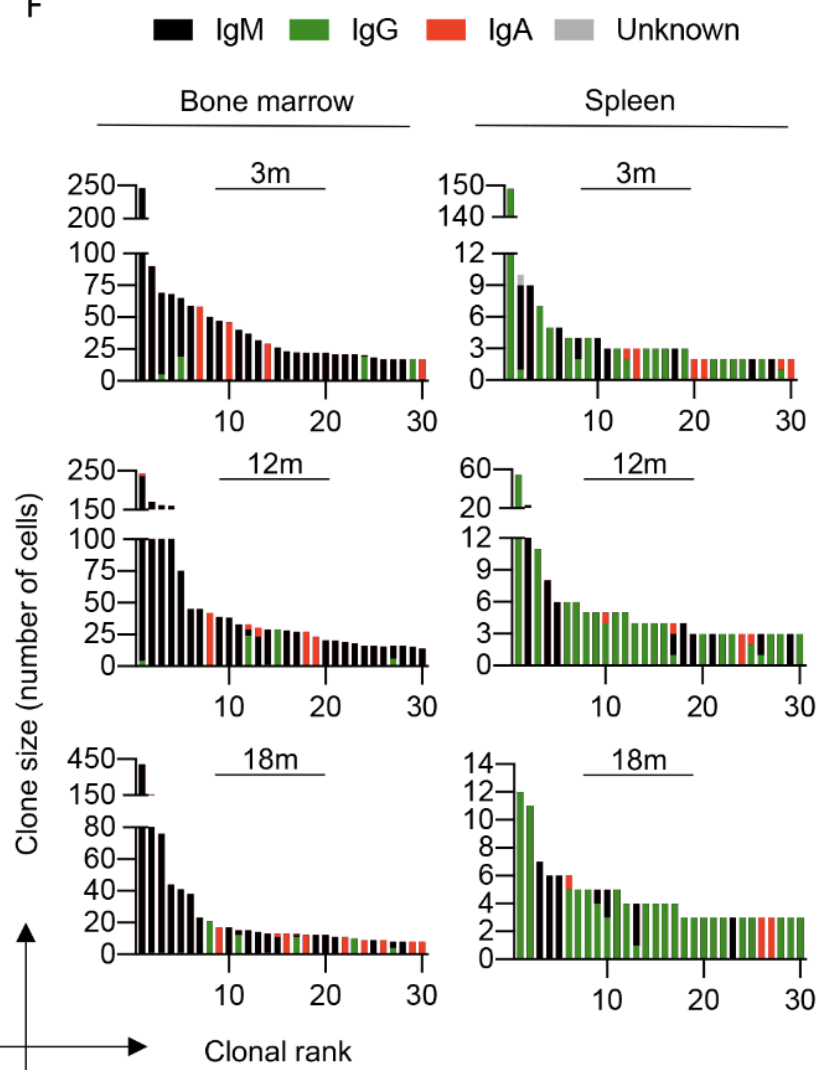

Figure 1. Single-cell immune repertoire sequencing reveals clonal expansion and class-switching in the bone marrow plasma cell and splenic B cell repertoire following TNFR2 immunization. A. Experimental overview of TNFR2 
Agrafiotis et al. 13

immunization, bone marrow (BM) plasma cell (PC) and splenic (SP) B cell isolation, single-cell immune repertoire sequencing. B. Mean number of cells per isotype for each immunized cohort. Only cells containing exactly one variable heavy $(\mathrm{VH})$ and variable light $(\mathrm{VL})$ chain were retained in the analysis. Colors correspond to isotype. C. Mean number of clones per isotype for each immunized cohort. Clones were determined by grouping those $\mathrm{B}$ cells containing identical $\mathrm{CDRH} 3+\mathrm{CDRL} 3$ amino acid sequences. The isotype was determined as the isotype corresponding to the majority of cells within one clone. Color corresponds to isotype. D. Distribution of clonal expansion. Each section corresponds to a unique clone and the size corresponds to the fraction of cells relative to the total repertoire. Unexpanded clones refers to those clones supported by only one unique cell barcode (colored red). One representative mouse per age and organ cohort is shown. E. Clonal frequency for the top 30 most expanded clones in each repertoire. One representative mouse per age and organ cohort is shown. F. Relationship between the number of unique amino acid variants and the number of cell barcodes for the top 30 clones separated by isotype. 


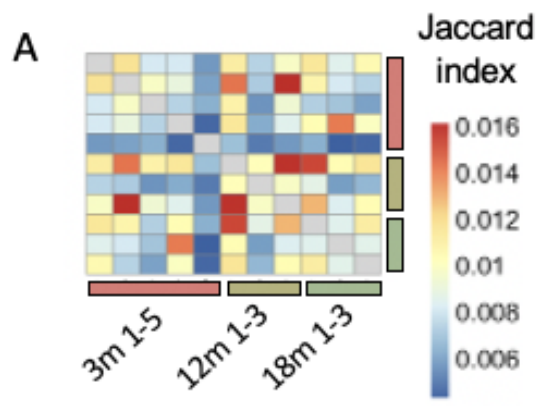

D

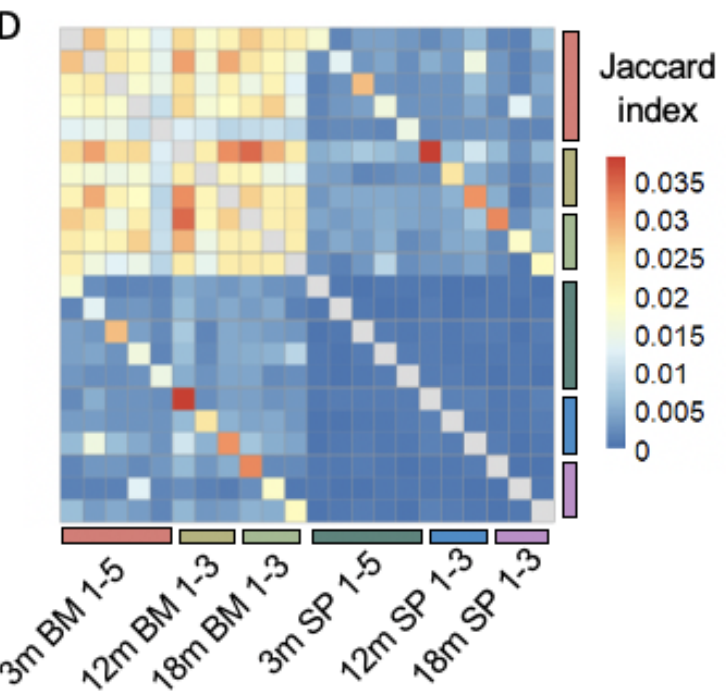

G

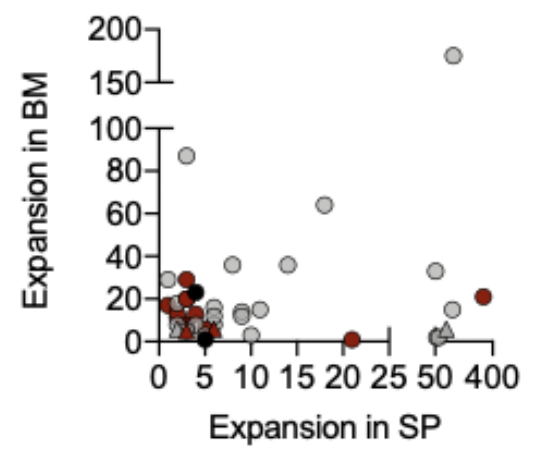

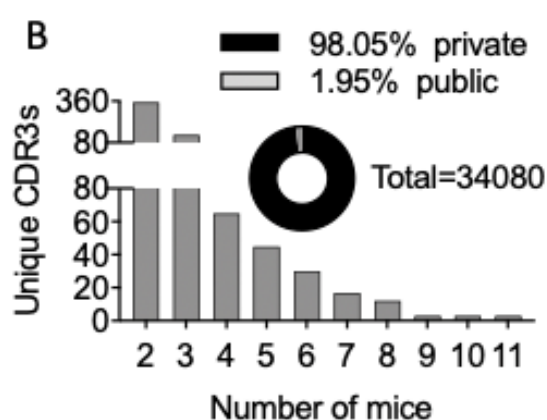

E

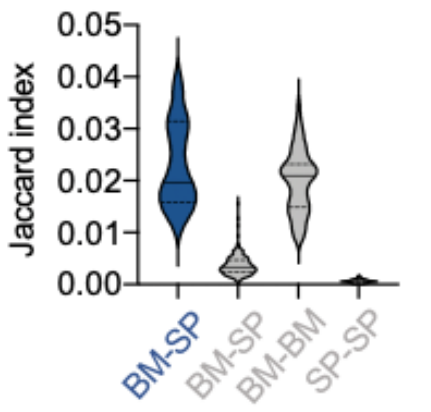

Within the same mouse
Across mice

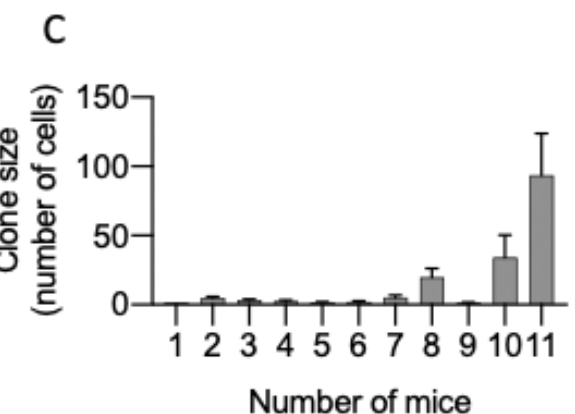

F

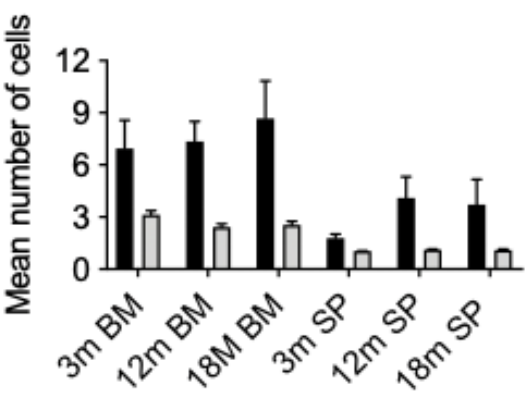

- Organ overlapping $\square$ Organ specific

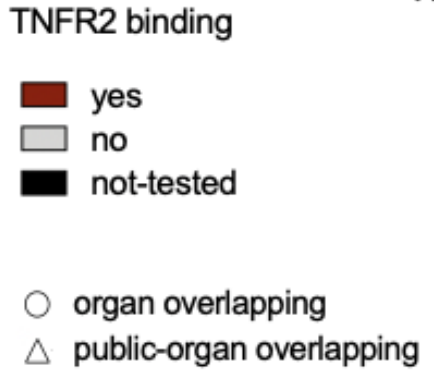

$\mathrm{H}$

\section{Organ overlapping}

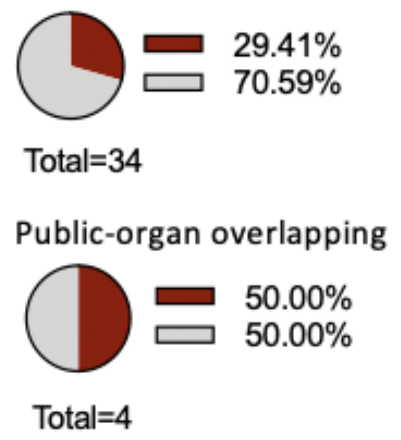

Figure 2. Public and organ overlapping clones show TNFR2 specificity. A. Jaccard index quantifying the number of identical clones found between mice. Clones were determined by grouping those $\mathrm{B}$ cells containing identical $\mathrm{CDRH} 3+\mathrm{CDRL} 3$ amino acid sequences. B. Number of unique clones found in two or more mice. C. Quantification of the clonal expansion of clones found in one or more mice. D. Jaccard index quantifying the number of identical clones found between samples. E. Jaccard index quantifying clonal overlap across organs either within the same mouse or across all mice. F. Mean clonal expansion between organ-overlapping and organ-specific clones. G. Relationship between the clonal expansion in the bone marrow and in the spleen for those organ overlapping clones that were tested for binding to TNFR2. For each clone, the antibody variant (combined $\mathrm{VH}+\mathrm{VL}$ nucleotide sequence) supported by the most unique cell barcodes was selected to be expressed. Color corresponds to TNFR2 binding. Shape indicates mouse-specific or public clones. $\mathrm{H}$. Overall statistics of binding ability for the tested clones. 
Agrafiotis et al. 15

young

A
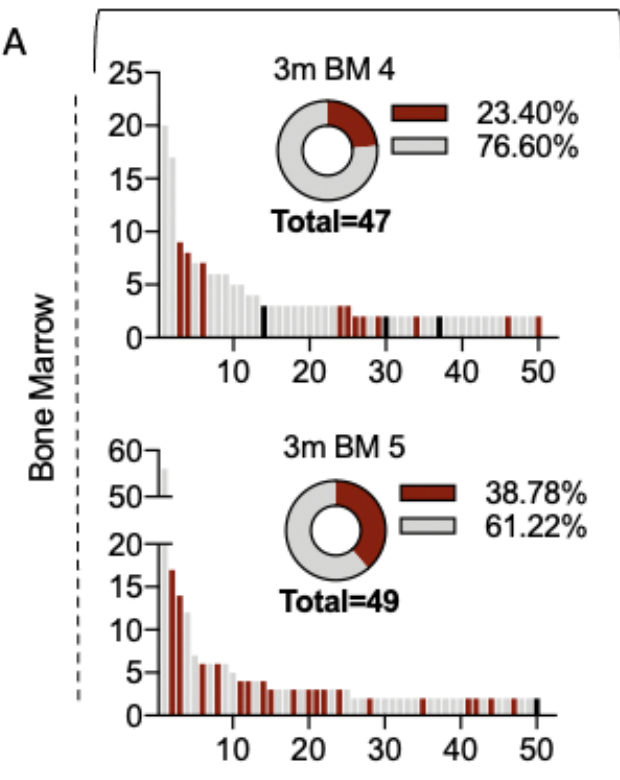

young

B
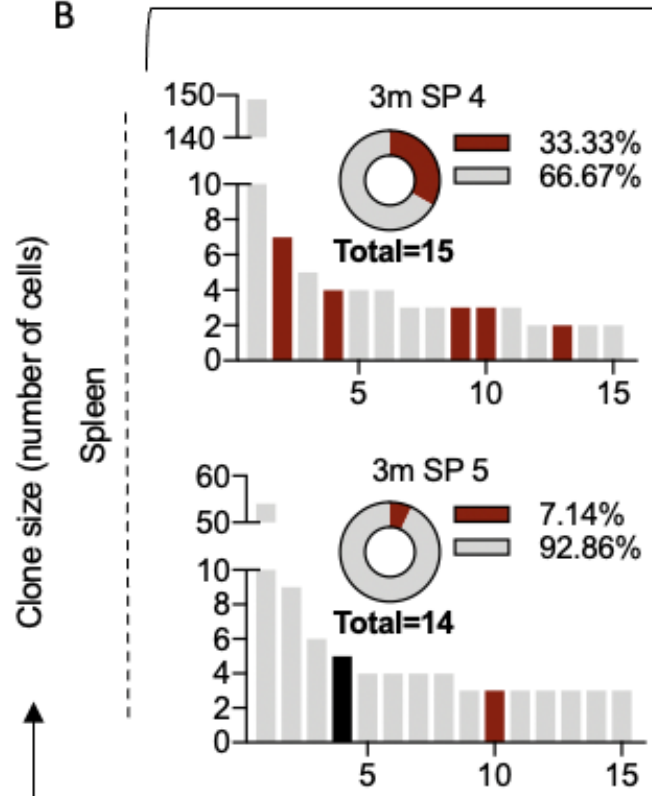

old
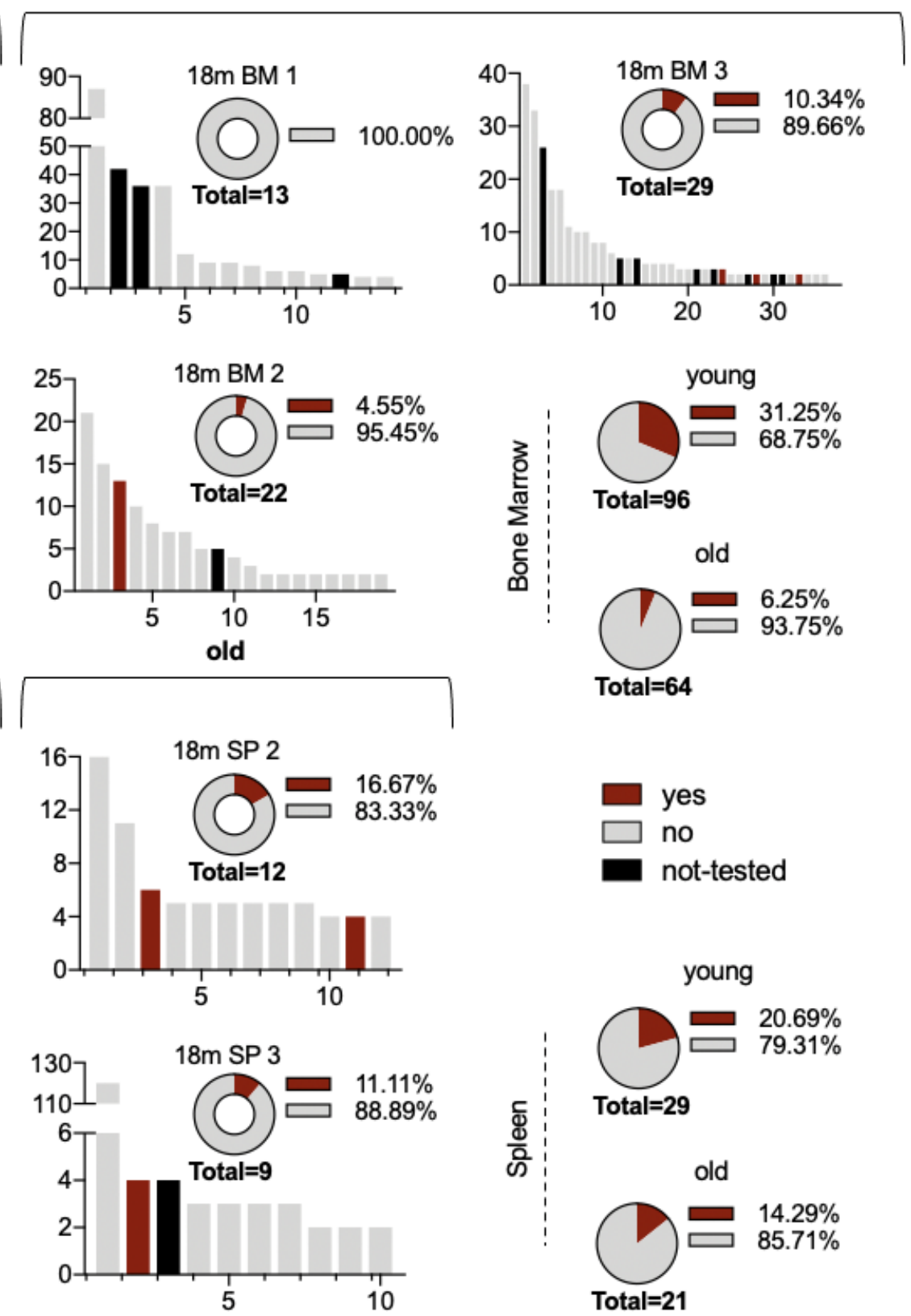

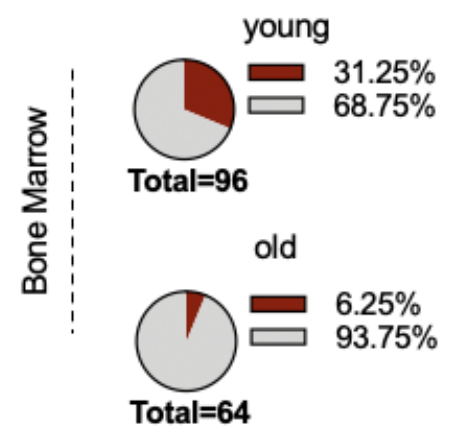

Total $=64$
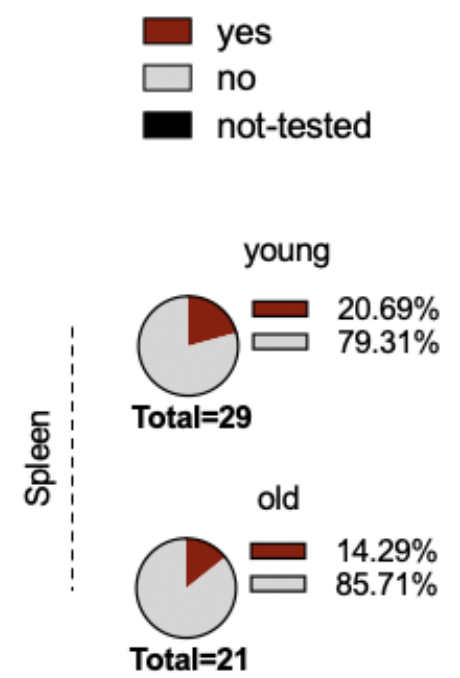

Clonal rank

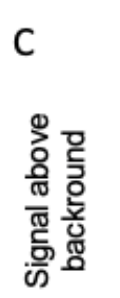

- Young expande

- Old expanded

$\triangle$ Private organ overlapping

$\checkmark$ Public organ overlapping
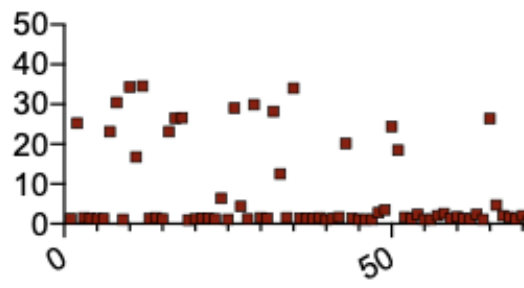

50

\section{0}

150

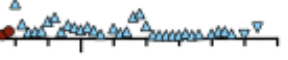
200

Figure 3. Clonal expansion is correlated with TNFR2 specificity in young but not old mice. A. \& B. Clonal rank plot of expanded IgG clones indicating TNFR2-specific clones in young and old bone marrow (A) and splenic (B) repertoires. Clone was determined by grouping those $B$ cells containing identical CDRH3+CDRL3 amino acid sequences. Only cells containing exactly one variable heavy $(\mathrm{VH})$ and variable light $(\mathrm{VL})$ chain were considered. The isotype was determined as the isotype corresponding to the majority of cells within one clone. For each clone, the antibody variant (combined VH+VL nucleotide sequence) supported by the most unique cell barcodes was selected to be expressed. Overall statistics of 
bioRxiv preprint doi: https://doi.org/10.1101/2021.11.09.467876; this version posted November 11,2021 . The copyright holder for this preprint (which was not certified by peer review) is the author/funder, who has granted bioRxiv a license to display the preprint in perpetuity. It is made available under aCC-BY-ND 4.0 International license.

Agrafiotis et al. 16

binding ability for the clones tested are also shown. C. The ELISA signal of duplicate ELISA measurements at $450 \mathrm{~nm}$ is shown for all clones tested (both overlapping and expanded) relative to a negative background control. 
bioRxiv preprint doi: https://doi.org/10.1101/2021.11.09.467876; this version posted November 11,2021 . The copyright holder for this preprint (which was not certified by peer review) is the author/funder, who has granted bioRxiv a license to display the preprint in perpetuity. It is made available under aCC-BY-ND 4.0 International license.

Agrafiotis et al. 17

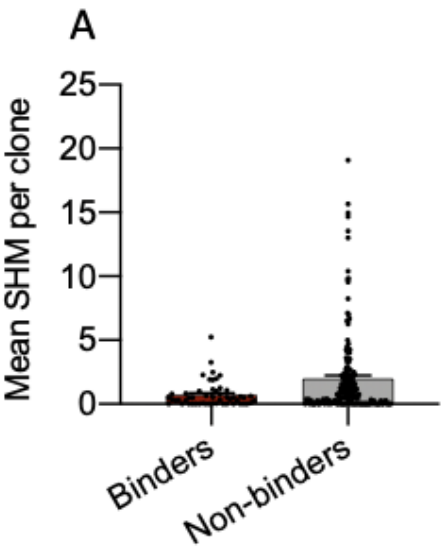

B

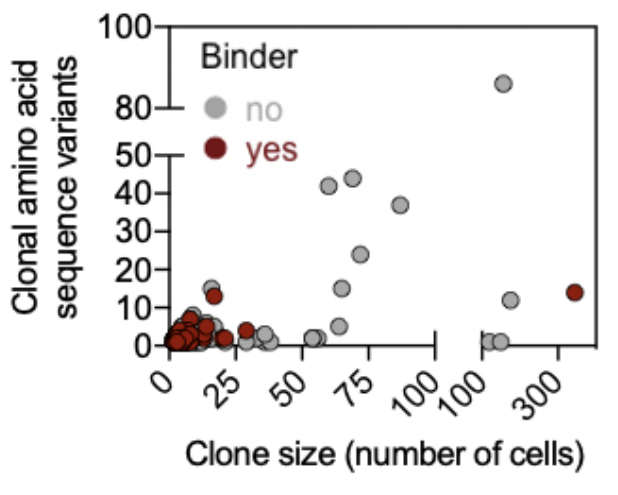

C

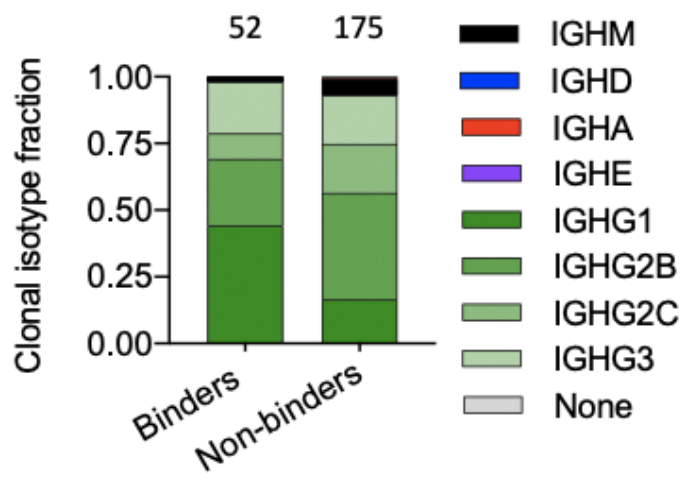

D
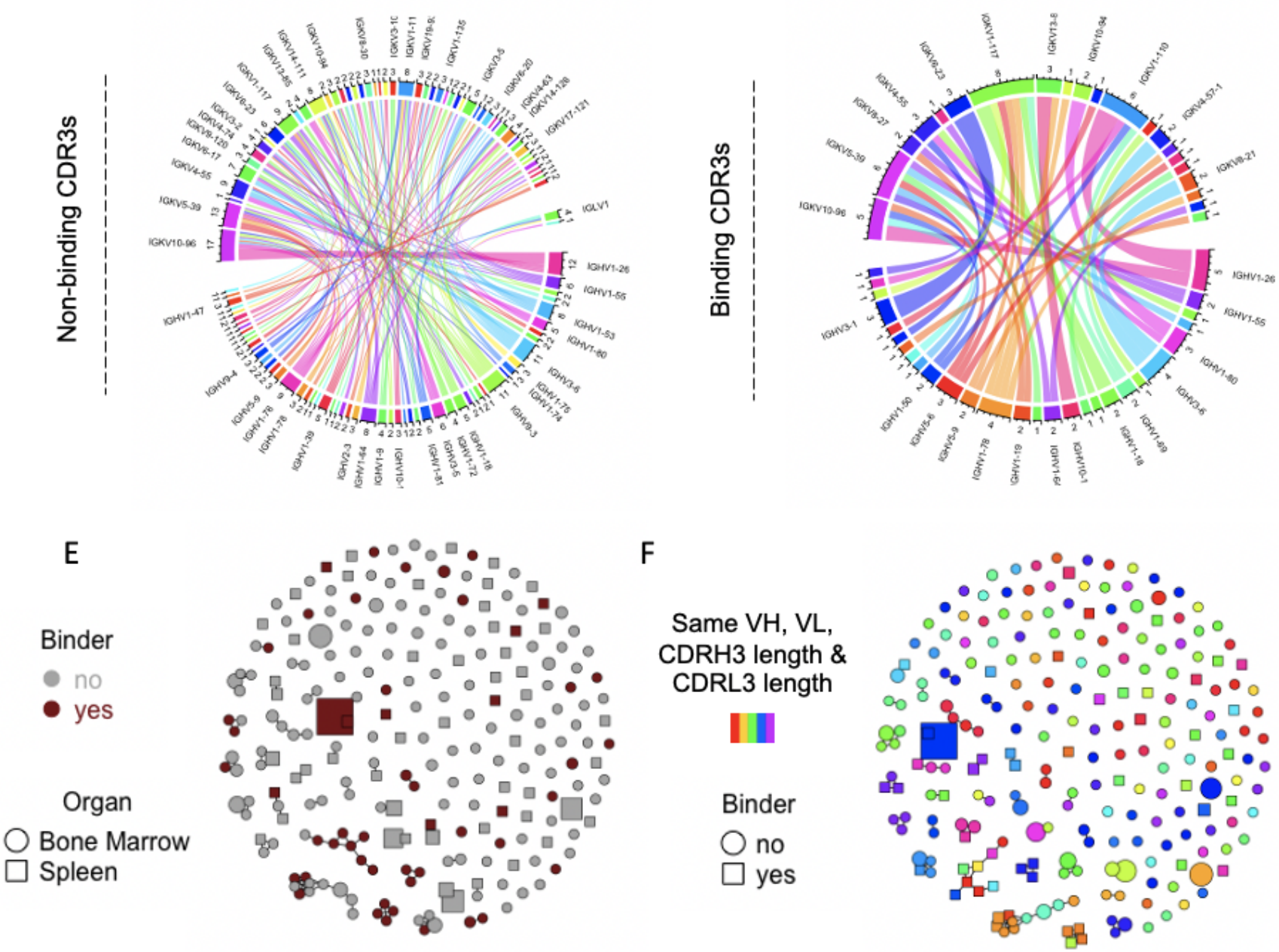

G

Non-binding CDRH3s

Binding $\mathrm{CDRH} 3 \mathrm{~s}$

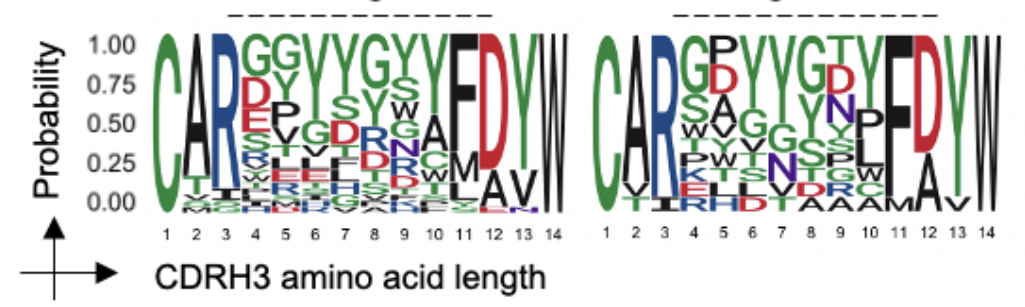

Acidic Basic

Hydrophobic $\square$ Neutral $\square$ Polar

Figure 4. TNFR2-specific clones have distinct repertoire features. A. Mean number of nucleotide somatic hypermutations (SHMs) per TNFR2-specific and -unspecific clones. Mutations were calculated in the full-length $\mathrm{V}$ and $\mathrm{J}$ 
bioRxiv preprint doi: https://doi.org/10.1101/2021.11.09.467876; this version posted November 11,2021 . The copyright holder for this preprint (which was not certified by peer review) is the author/funder, who has granted bioRxiv a license to display the preprint in perpetuity. It is made available under aCC-BY-ND 4.0 International license.

Agrafiotis et al. 18

regions across both heavy $(\mathrm{HC})$ and light chain (LC). Clone was determined by grouping those $B$ cells containing identical CDRH3+CDRL3 amino acid sequences. B. Relationship between the number of unique amino acid variants and the number of cell barcodes for the clones tested for TNFR2 specificity. C. Isotype distribution for the confirmed TNFR2 binders and non-binders on the clonal level. D. Circos plots depicting the relationship between HC and LC V genes. Color corresponds to the different $\mathrm{V}$ genes. Edges illustrate the number of clones using each particular combination. E. Similarity network of TNFR2-specific and -unspecific B cell clones. Nodes represent unique clones. Edges connect those clones separated by an edit distance of 5 amino acids or less. Color corresponds to TNFR2 specificity. Shape indicates organ of origin. F. Same similarity network as (E) with color indicating clones with identical germline genes and CDR3 lengths. Shape indicates TNFR2 specificity. G. Sequence logo plots of the confirmed TNFR2-binding and non-binding CDRH3 sequences for the most frequent CDRH3 length. 
A

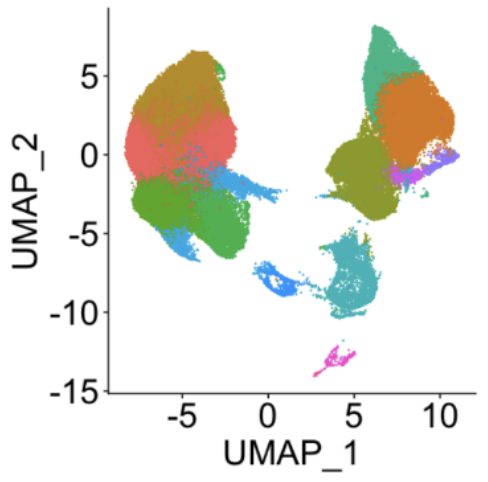

C
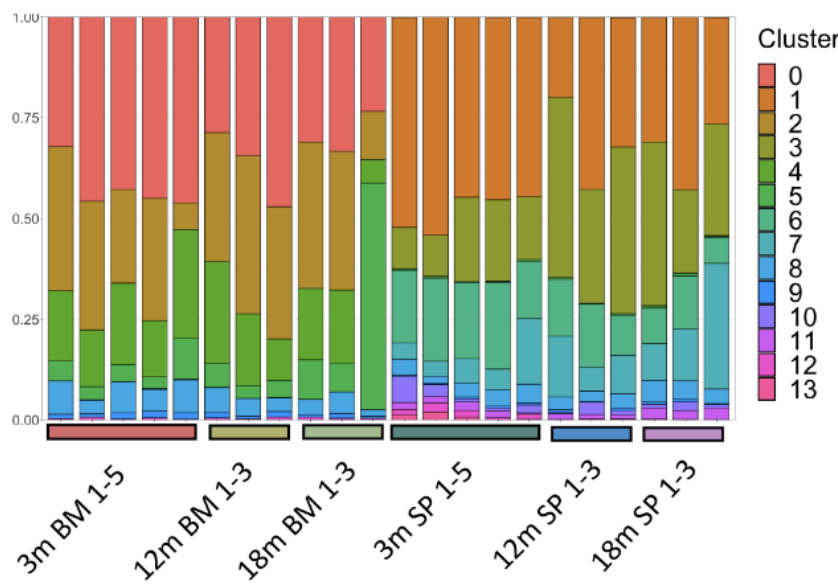

Spleen

$\mathrm{E}$

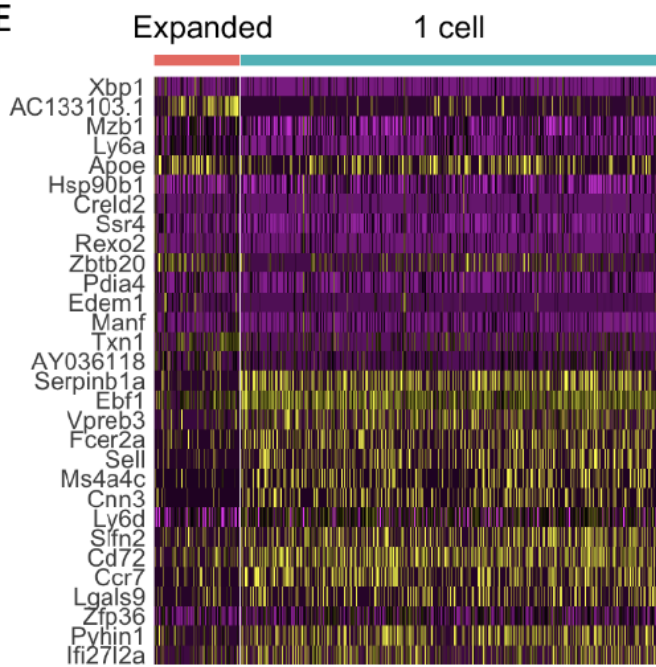

B

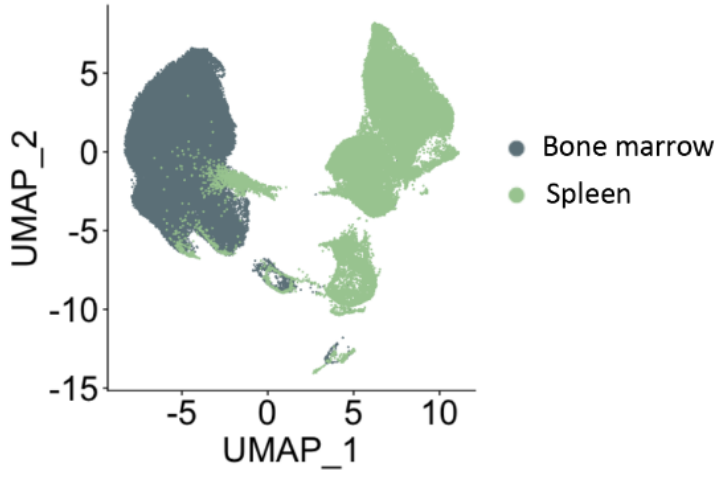

D
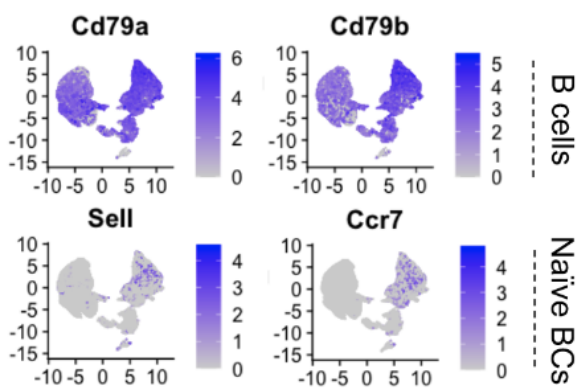

Cd19
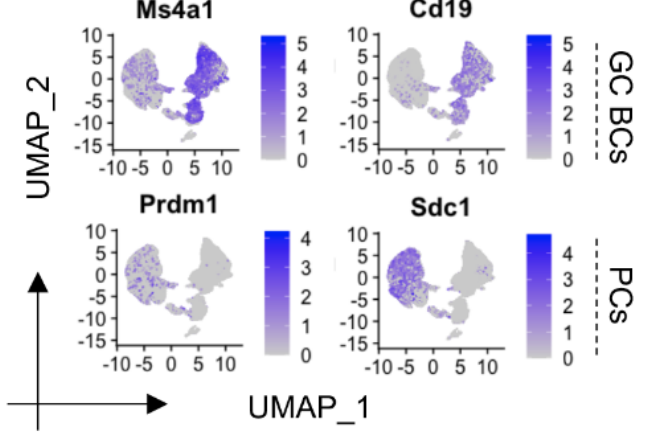

Expression $\mathrm{F}$

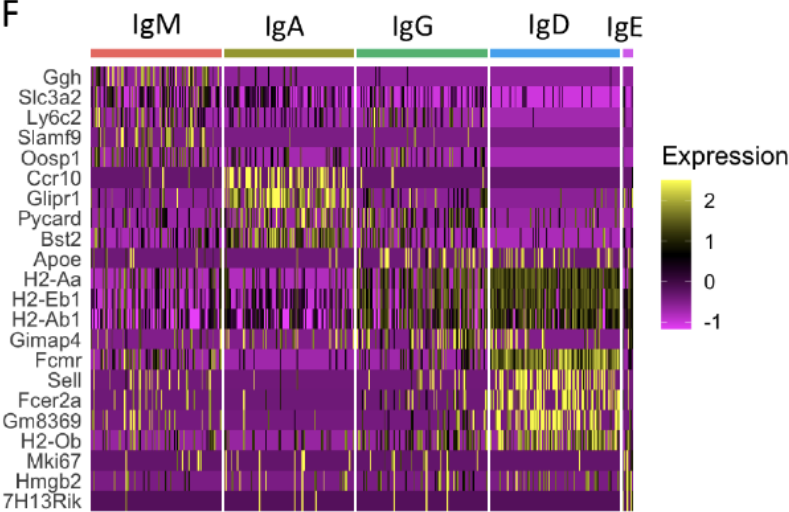

Figure 5. scRNA reveals organ, expansion and isotype transcriptional heterogeneity. A. Uniform manifold approximation projection (UMAP) based on total gene expression of all repertoires following TNFR2 immunization. Each point corresponds to a cell and color corresponds to the transcriptional cluster. B. UMAP split by organ. C. Cluster membership separated by isotype following TNFR2 immunization. Color indicates the transcriptional cluster from (A). D. UMAP plots showing gene expression for selected genes. E. Differentially expressed genes between highly-expanded and lowly-expanded splenic B cells following TNFR2 immunization. The order of genes (from top to bottom) corresponds to the highest average log fold change. All genes displayed have adjusted $p$ values $<0.01$. F. Differentially expressed genes between isotypes. 
Agrafiotis et al. 20

A

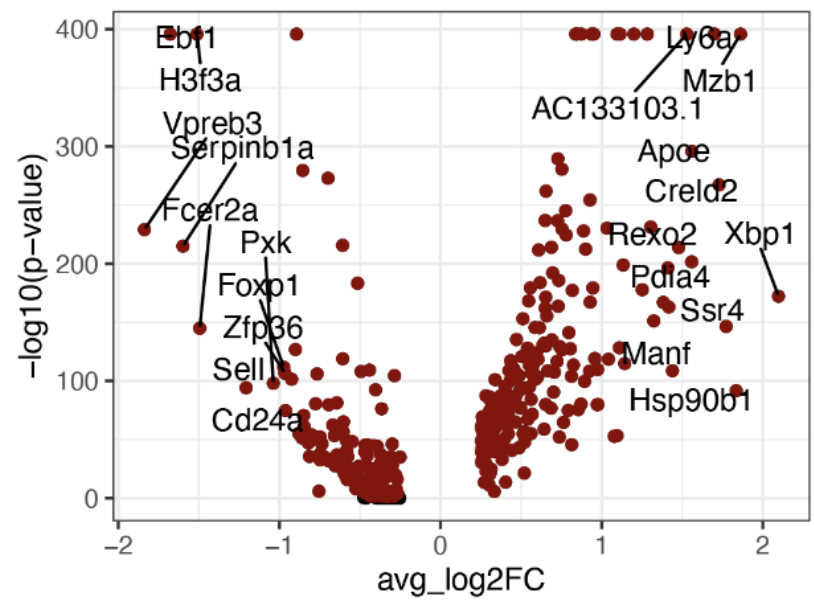

C TNFR2-specific vs non specific sequences

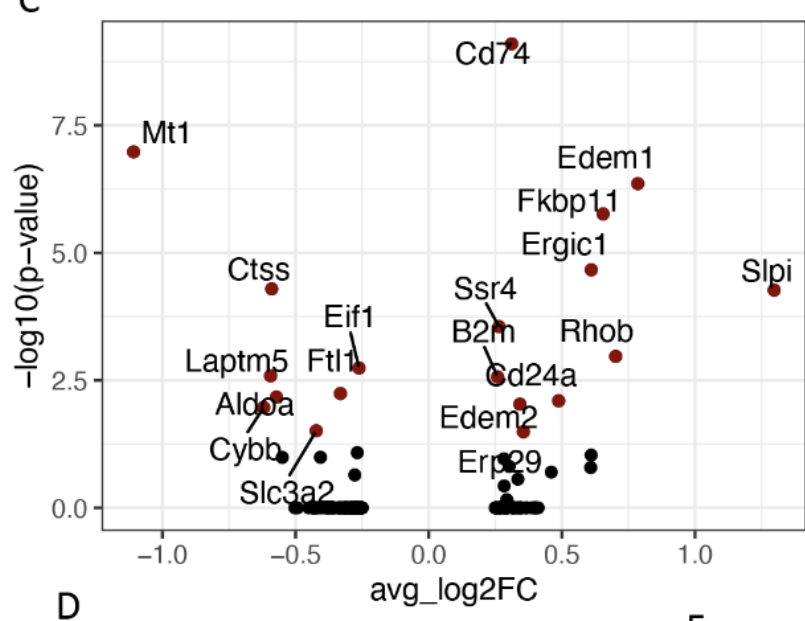

B
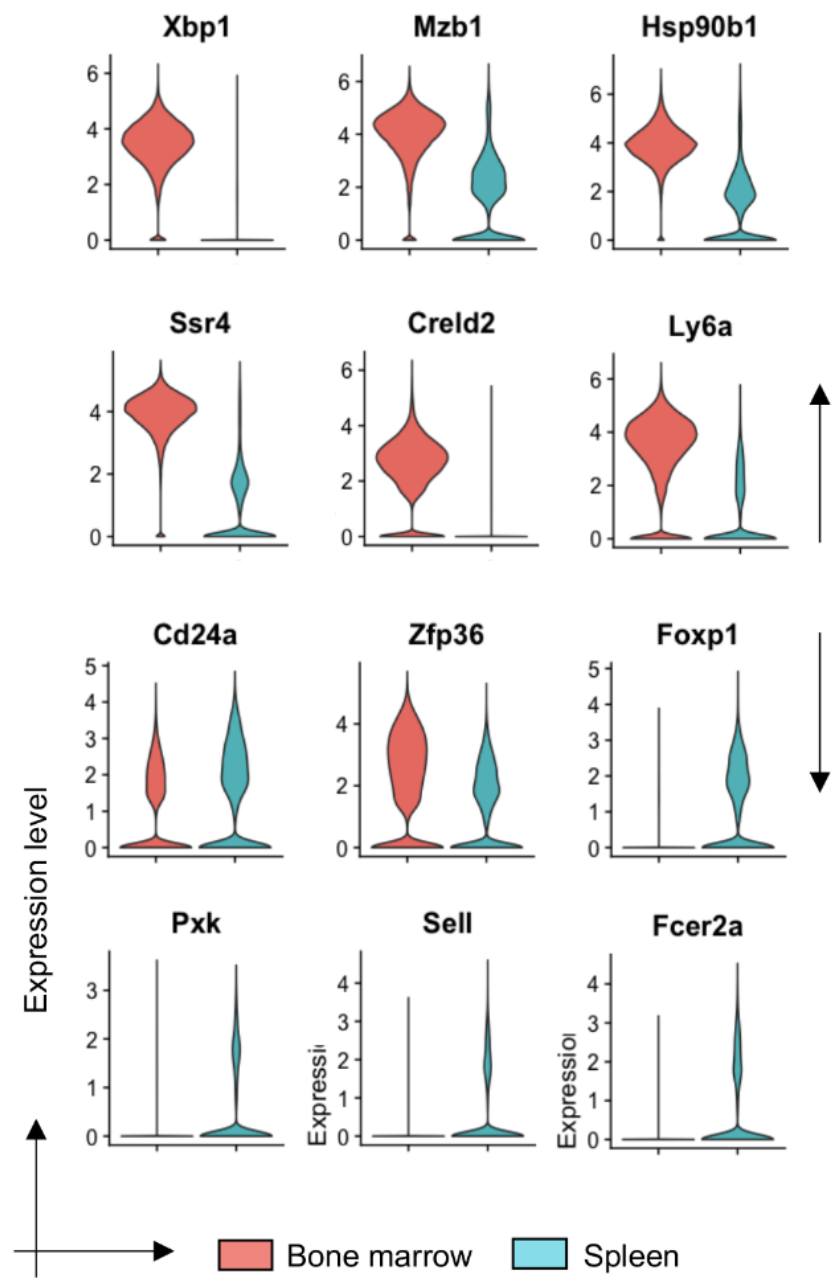

Sell
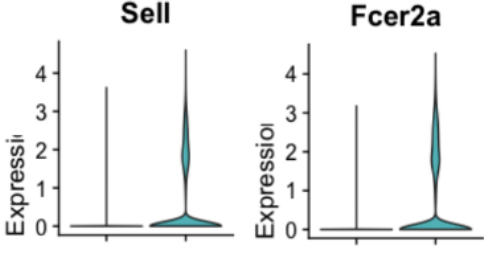

Bone marrow

Spleen
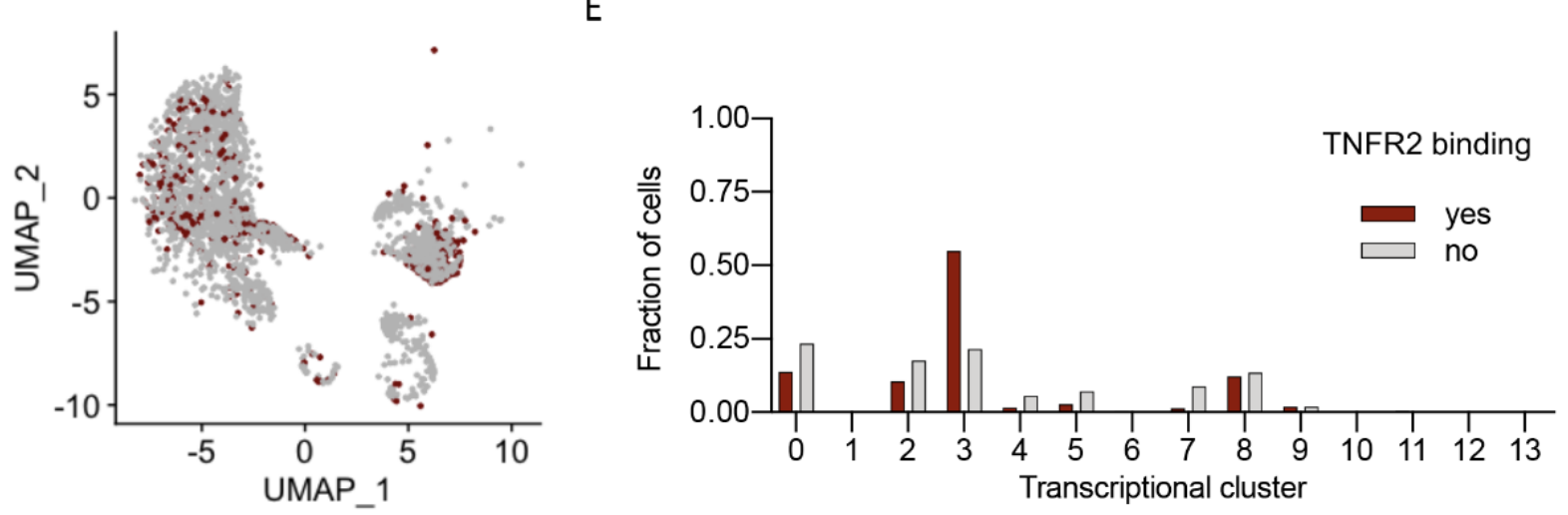

Figure 6. Organ-overlapping but not antigen-specific clones have distinct transcriptional signatures. A. Differential gene expression between private (only found in spleen) and overlapping (clone found in both organs of an individual mouse) splenic B cells. Points in red indicate significantly differentially expressed genes ( $p$-adj $<0.01)$. B. Expression levels of the most up and down regulated genes from $(A)$ across organs. C. Differentially expressed genes between binding and nonbinding cell barcodes from the BM. D. Location of the confirmed TNFR2 binders and non-binders on the UMAP. E. Cluster membership of binding and non-binding cells. 
bioRxiv preprint doi: https://doi.org/10.1101/2021.11.09.467876; this version posted November 11,2021 . The copyright holder for this preprint (which was not certified by peer review) is the author/funder, who has granted bioRxiv a license to display the preprint in perpetuity. It is made available under aCC-BY-ND 4.0 International license.

Agrafiotis et al. 21

Supporting information for

B cell clonal expansion is correlated with antigen-specificity in young but not old mice

Andreas Agrafiotis ${ }^{1,2, \star}$, Daniel Neumeier ${ }^{1}$, Kai-Lin Hong ${ }^{1}$, Tasnia Chowdhury ${ }^{3}$, Roy Ehling ${ }^{1}$, Raphael Kuhn ${ }^{1}$, loana Sandu $^{2}$, Victor Kreiner ${ }^{1}$, Dale Starkie ${ }^{3}$, Daniel J. Lightwood ${ }^{3}$, Annette Oxenius ${ }^{2}$, Sai T. Reddy,\#, Alexander Yermanos ${ }^{1,2,4, \#}$

${ }^{1}$ Department of Biosystems Science and Engineering, ETH Zurich, Basel, Switzerland

${ }^{2}$ Institute of Microbiology, ETH Zurich, Zurich, Switzerland

${ }^{3}$ UCB Pharma, Berkshire, United Kingdom

${ }^{4}$ Department of Pathology and Immunology, University of Geneva, Geneva, Switzerland

"Correspondence: sai.reddy@ethz.ch ; ayermanos@gmail.com 
Agrafiotis et al. 22
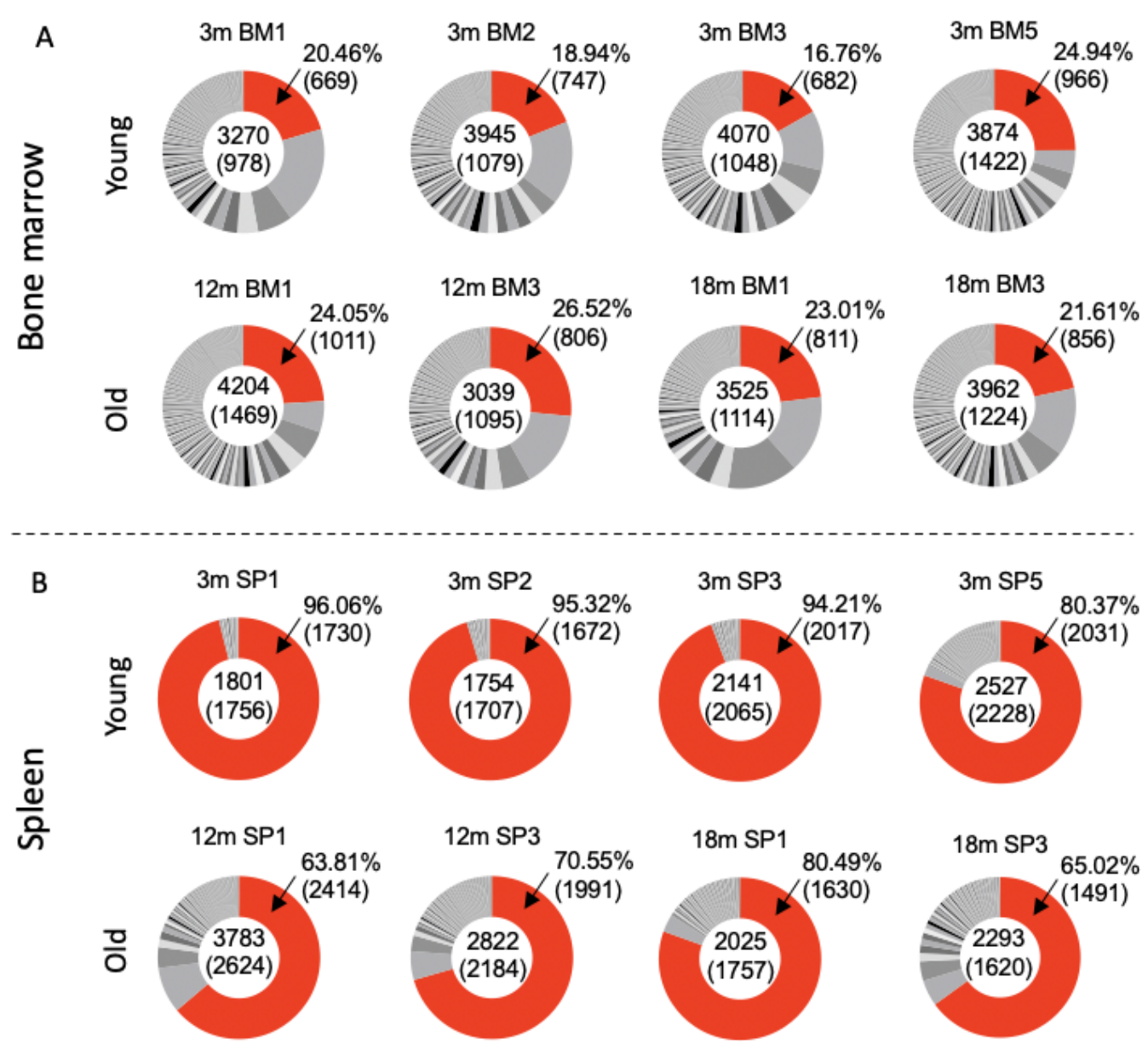

Figure S1. Clonal expansion of bone marrow (A) and spleen (B) repertoires. Each section in the circle corresponds to a unique clone and the size corresponds to the fraction of cells relative to the total number of cells found in each repertoire. Unexpanded clones were defined as those clones supported by only one unique cell barcode (red color).

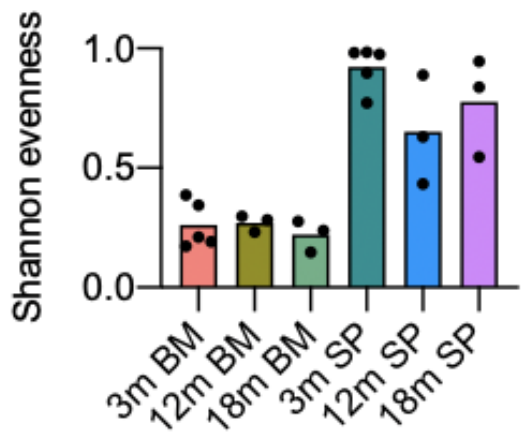

Figure S2. Shannon evenness quantifying clonal expansion of bone marrow (BM) plasma cells and splenic (SP) B cells. Each individual point corresponds to a repertoire arising from a 3-month-old (3m), 12-months-old $(12 \mathrm{~m})$, or 18-month-old $(18 \mathrm{~m})$ mouse. Colors correspond to the different age and organ cohorts. 

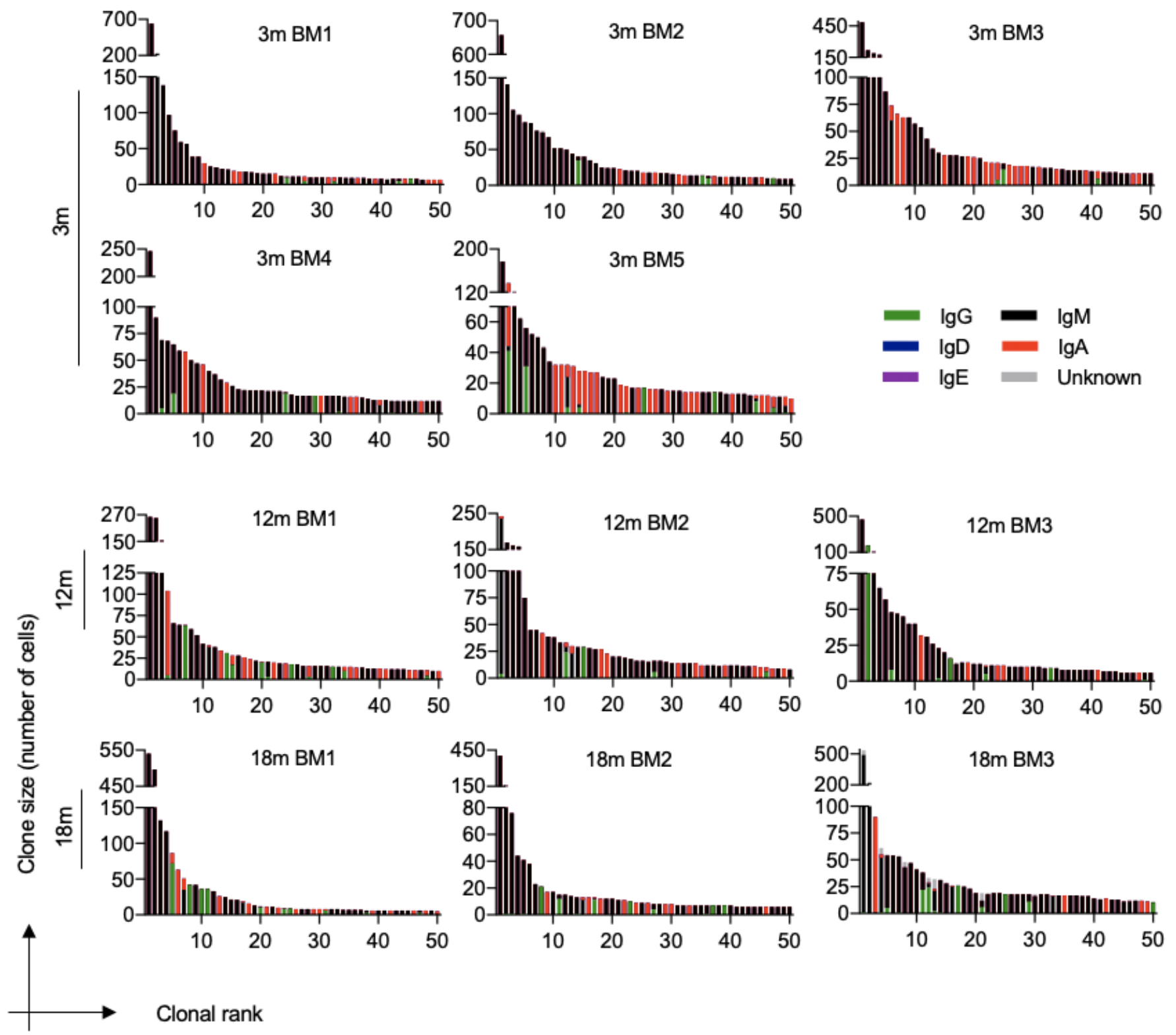

Figure S3. Clonal expansion for the top $\mathbf{5 0}$ most expanded clones of the bone marrow (BM) plasma cells for each immunized mouse. Clones were determined by grouping those $\mathrm{B}$ cells containing identical CDRH3+CDRL3 amino acid sequences. Color corresponds to isotype. Each plot corresponds to a repertoire arising from a 3-month-old $(3 \mathrm{~m}), 12-$ months-old (12m), or 18-month-old (18m) mouse. 
Agrafiotis et al. 24
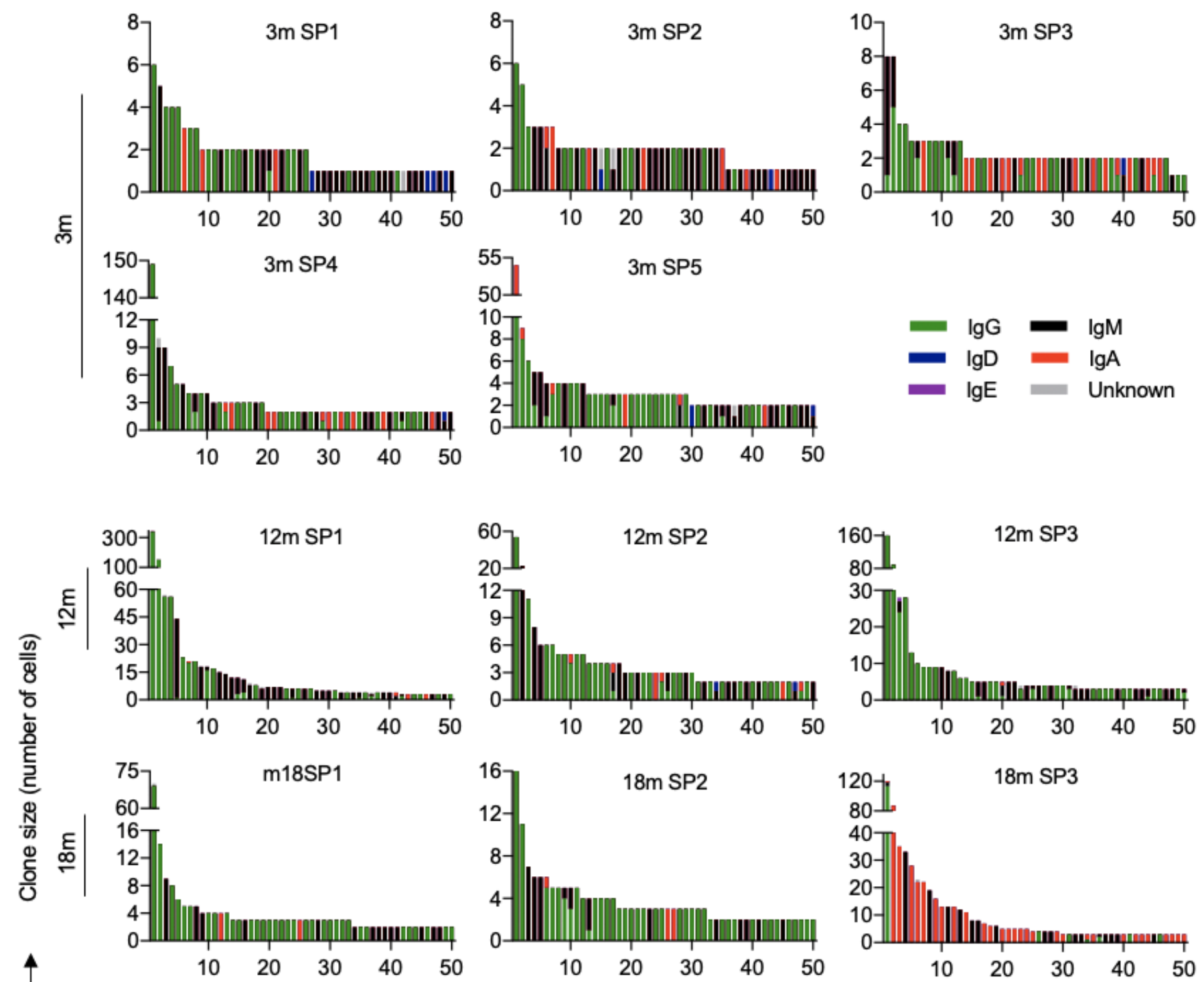

Figure S4. Clonal expansion for the top $\mathbf{5 0}$ most expanded clones of the splenic (SP) B cells for each immunized mouse. Clones were determined by grouping those B cells containing identical CDRH3+CDRL3 amino acid sequences. Color corresponds to isotype. Each plot corresponds to a repertoire arising from a 3-month-old (3m), 12-months-old (12m), or 18-month-old (18m) mouse. 
Agrafiotis et al. 25
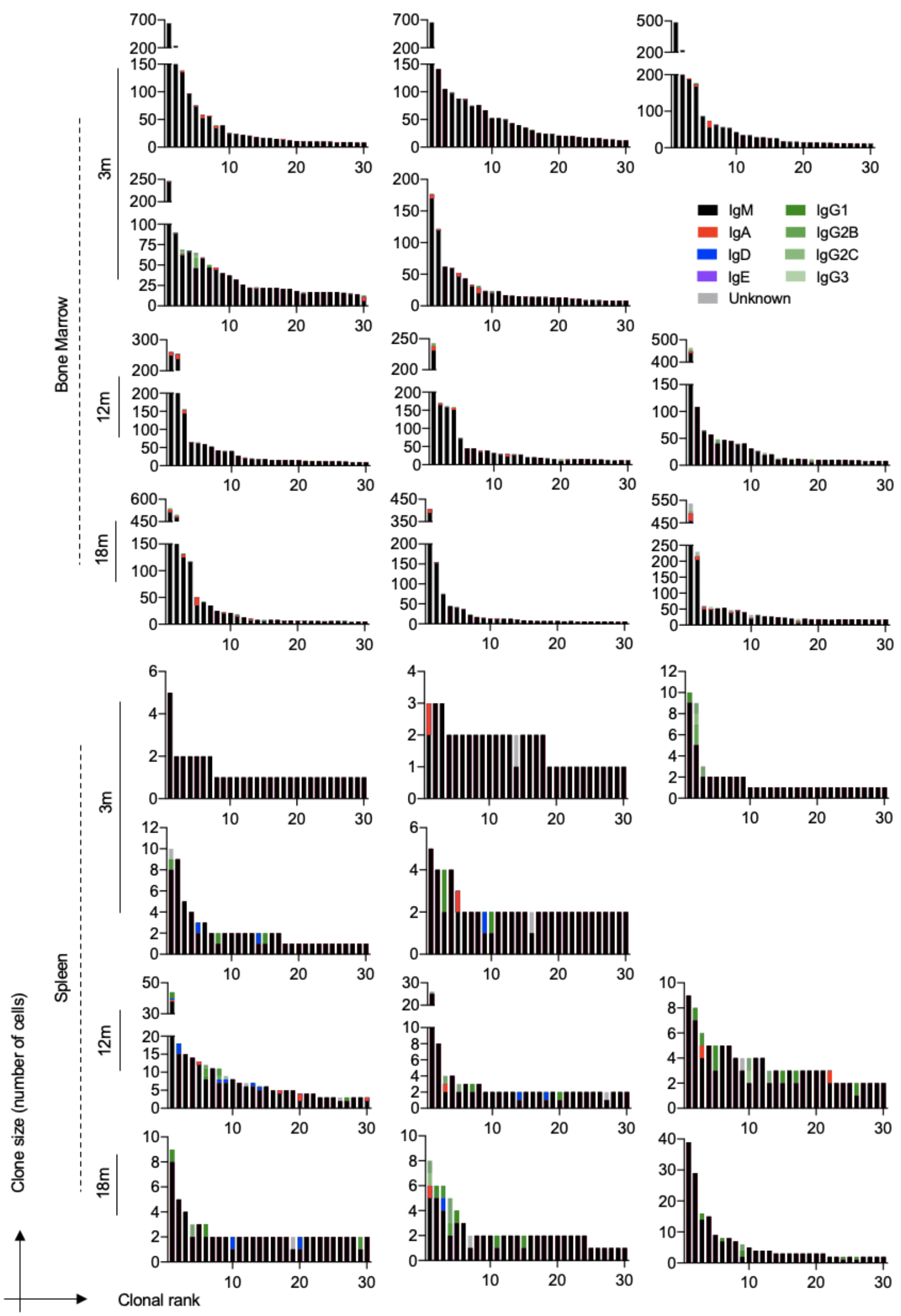
bioRxiv preprint doi: https://doi.org/10.1101/2021.11.09.467876; this version posted November 11, 2021. The copyright holder for this preprint (which was not certified by peer review) is the author/funder, who has granted bioRxiv a license to display the preprint in perpetuity. It is made available under aCC-BY-ND 4.0 International license.

Agrafiotis et al. 26

Figure S5. Clonal expansion for the top $\mathbf{3 0}$ most expanded clones with the majority of cells belonging to the IgM isotype of the bone marrow plasma and splenic B cells for each immunized mouse. Clones were determined by grouping those $\mathrm{B}$ cells containing identical $\mathrm{CDRH} 3+\mathrm{CDRL} 3$ amino acid sequences. 
Agrafiotis et al. 27
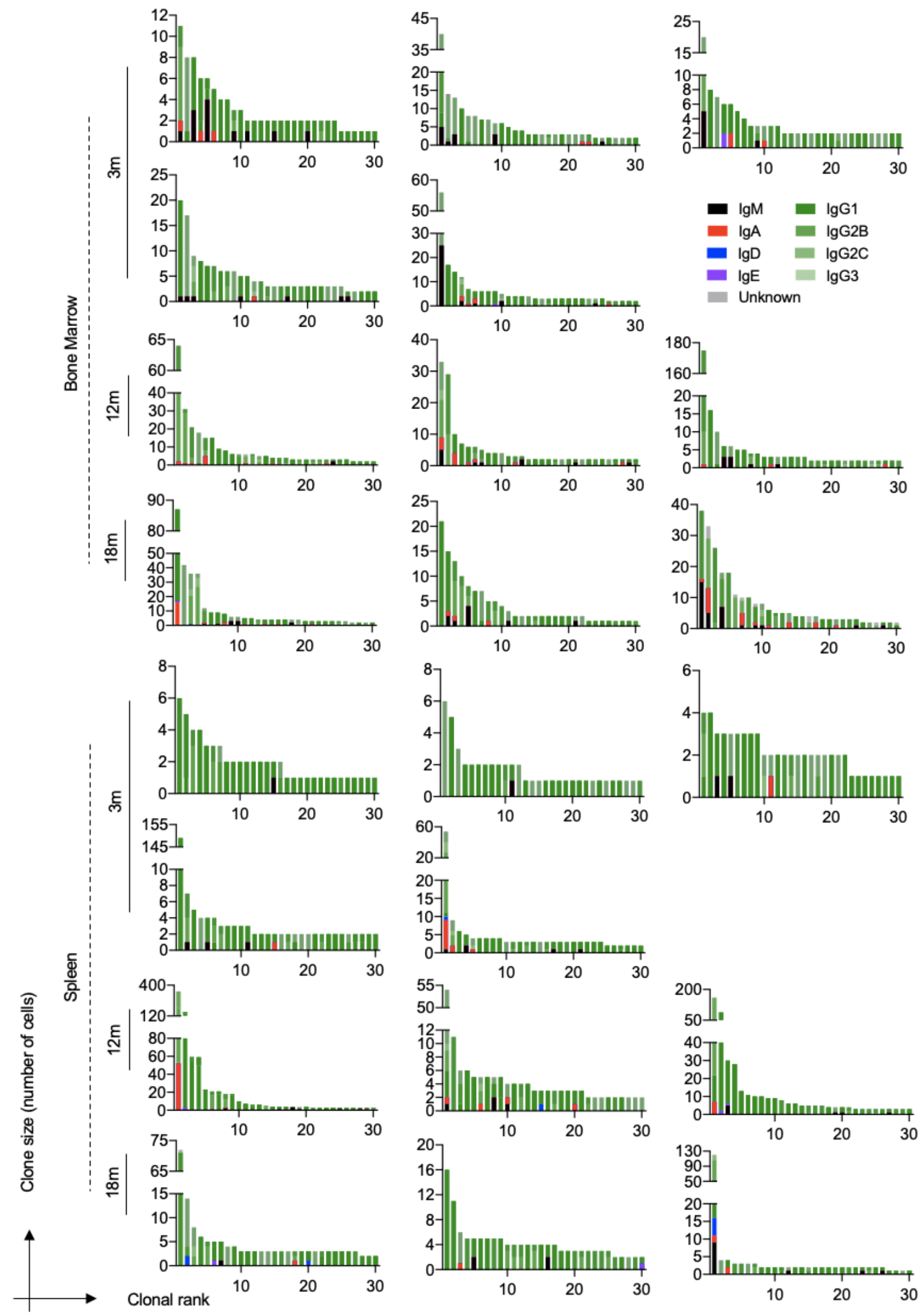

Figure S6. Clonal expansion for the top $\mathbf{3 0}$ most expanded clones with the majority of cells belonging to the lgG isotype of the bone marrow plasma and splenic B cells for each immunized mouse. Clones were determined by grouping those $\mathrm{B}$ cells containing identical CDRH3+CDRL3 amino acid sequences. 
bioRxiv preprint doi: https://doi.org/10.1101/2021.11.09.467876; this version posted November 11, 2021. The copyright holder for this preprint (which was not certified by peer review) is the author/funder, who has granted bioRxiv a license to display the preprint in perpetuity. It is made available under aCC-BY-ND 4.0 International license.

Agrafiotis et al. 28

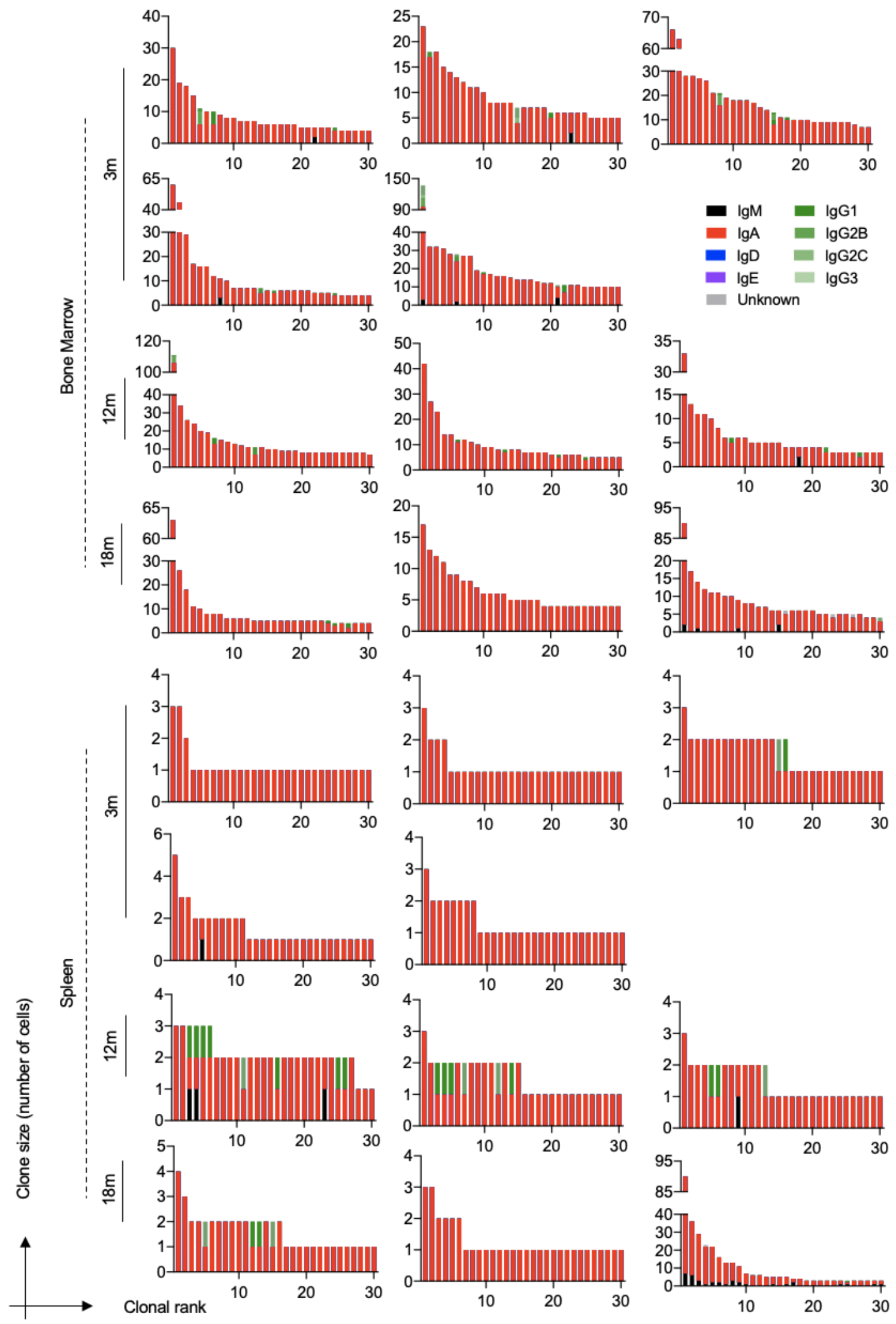


bioRxiv preprint doi: https://doi.org/10.1101/2021.11.09.467876; this version posted November 11, 2021. The copyright holder for this preprint (which was not certified by peer review) is the author/funder, who has granted bioRxiv a license to display the preprint in perpetuity. It is made available under aCC-BY-ND 4.0 International license.

Agrafiotis et al. 29

Figure S7. Clonal expansion for the top 30 most expanded clones with the majority of cells belonging to the IgA isotype of the bone marrow plasma and splenic B cells for each immunized mouse. Clones were determined by grouping those $\mathrm{B}$ cells containing identical $\mathrm{CDRH} 3+\mathrm{CDRL} 3$ amino acid sequences. 
bioRxiv preprint doi: https://doi.org/10.1101/2021.11.09.467876; this version posted November 11,2021 . The copyright holder for this preprint (which was not certified by peer review) is the author/funder, who has granted bioRxiv a license to display the preprint in perpetuity. It is made available under aCC-BY-ND 4.0 International license.

Agrafiotis et al. 30
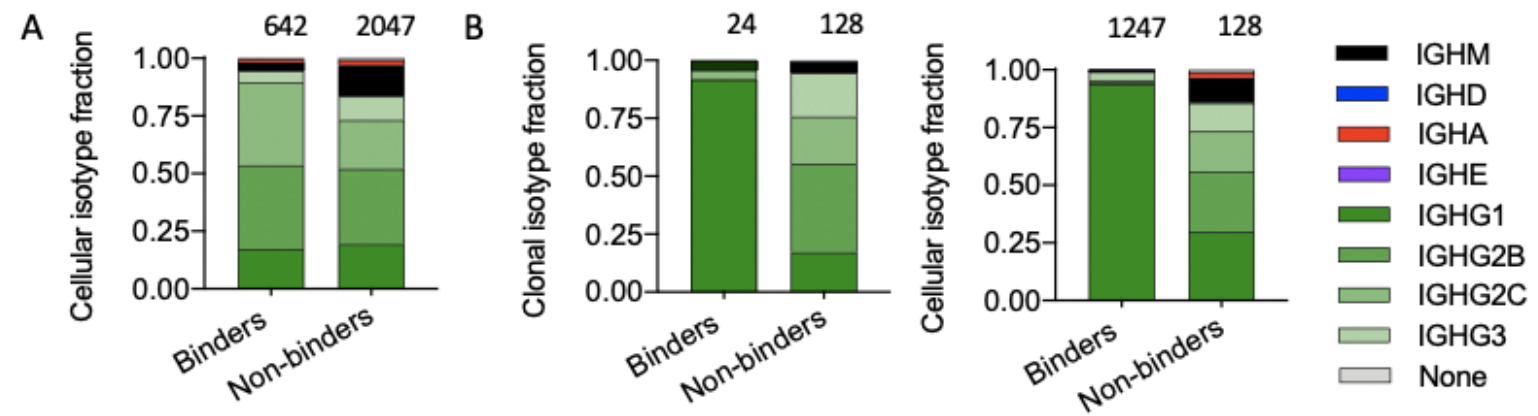

C

D

Non-binding CDR3s
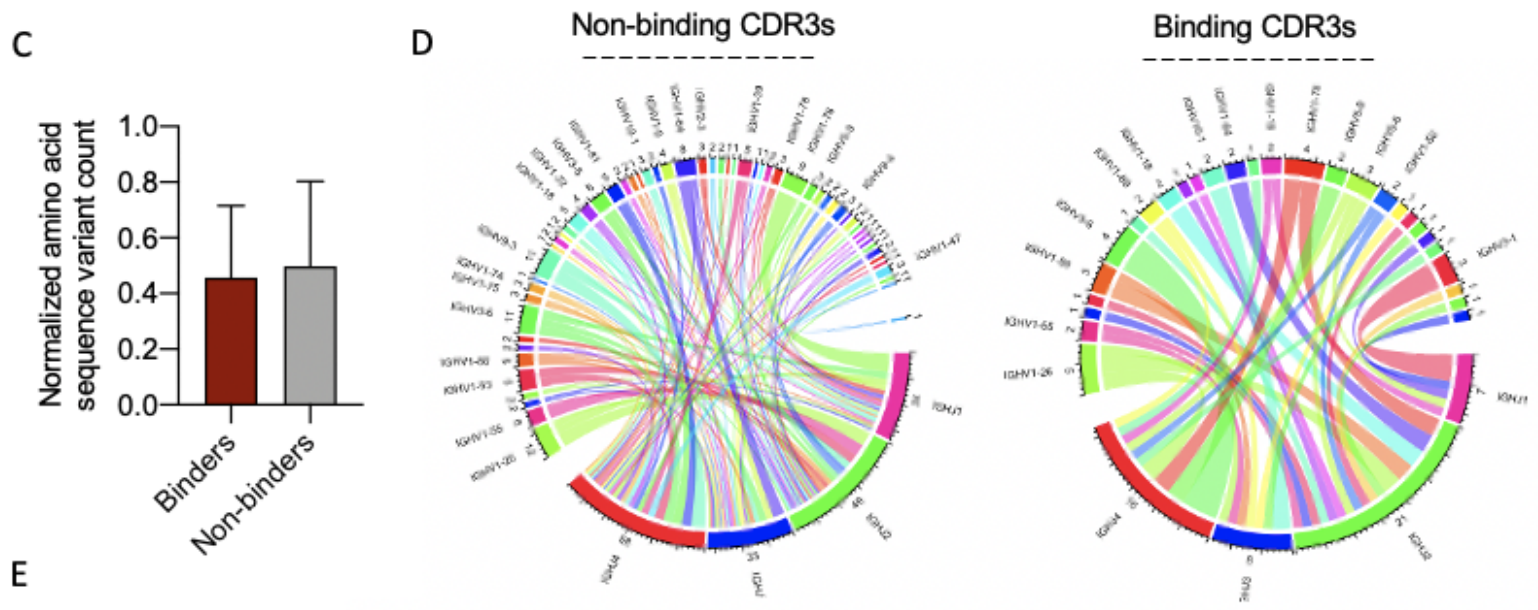

\section{Same VH, VL, CDRH3 length \& CDRL3 length}
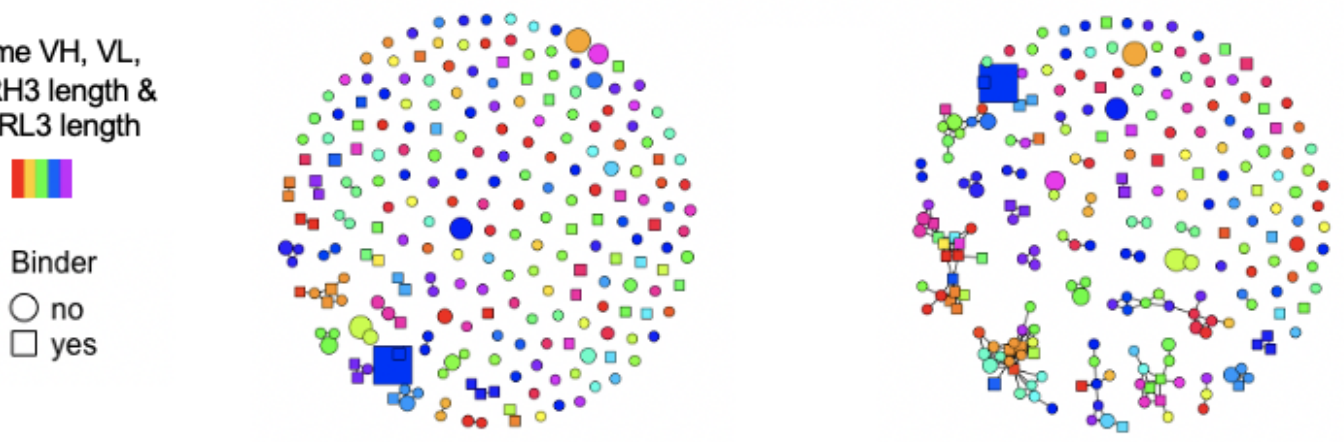

F

Distance 3

Distance 7

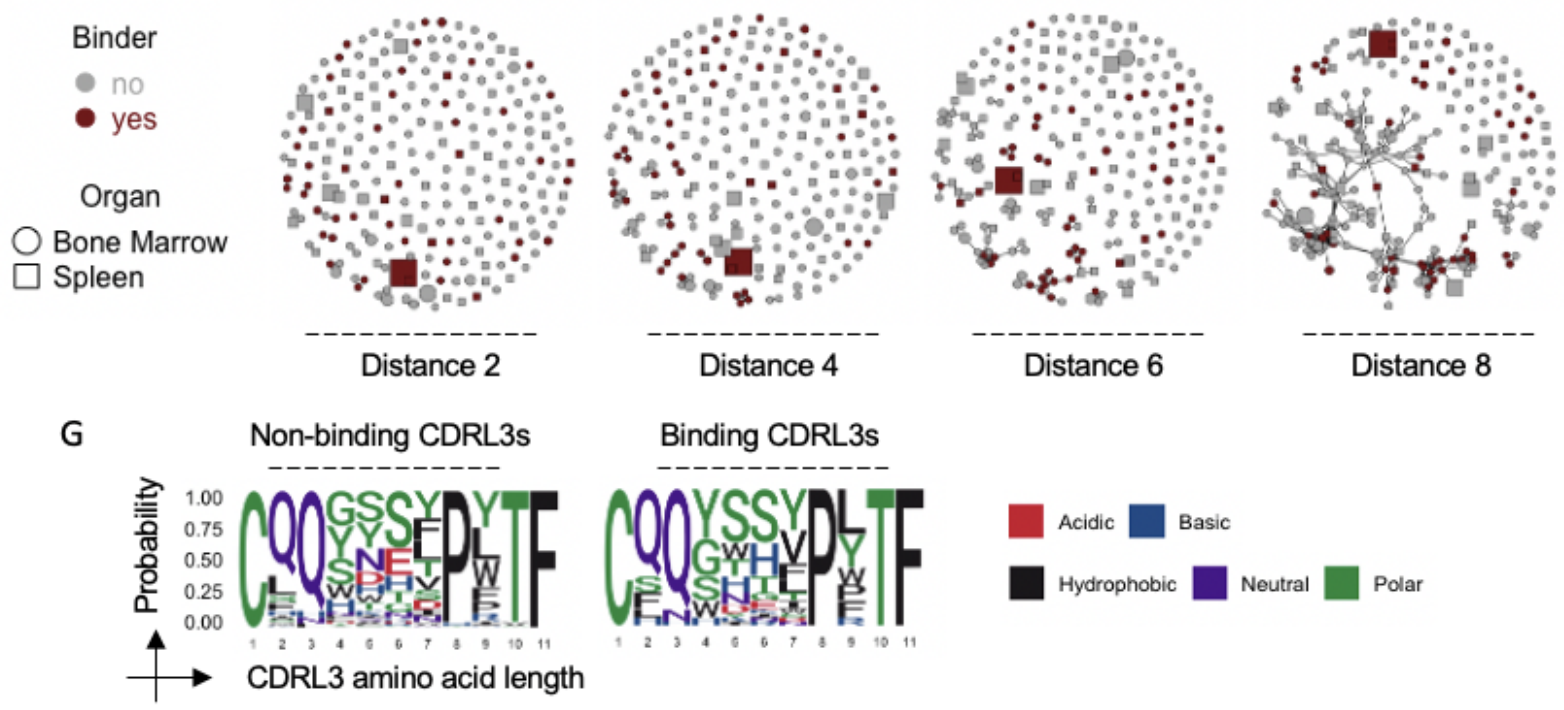


bioRxiv preprint doi: https://doi.org/10.1101/2021.11.09.467876; this version posted November 11, 2021. The copyright holder for this preprint (which was not certified by peer review) is the author/funder, who has granted bioRxiv a license to display the preprint in perpetuity. It is made available under aCC-BY-ND 4.0 International license.

Agrafiotis et al. 31

Figure S8. TNFR2-specific clones have distinct repertoire features. A. Isotype distribution for the confirmed TNFR2 binders and non-binders on the cellular level. B. Isotype distribution for the confirmed TNFR2 binders as in (A) but using a more stringent ELISA threshold to classify specificity ( $<2$ and $>10$ relative to background) $\mathrm{C}$. Normalized number of unique amino acid variants for the confirmed TNFR2 binders and non-binders. D. Circos plots depicting the relationship between $\mathrm{HC}$ and LC $\mathrm{J}$ gene usage. Color corresponds to the different $\mathrm{J}$ genes. Connections illustrate the number of clones using each particular combination. E. Similarity network of TNFR2-specific and -unspecific clones. Nodes represent a unique clone. Edges connect those clones separated by an edit distance of 2, 4, 6 and 8 amino acids or less. Color corresponds to TNFR2 specificity and shape indicates organ of origin. F. Same similarity network as $(E)$ with color indicating same variable HC, variable LC, CDRH3 length and CDRL3 length. Shape indicates TNFR2 specificity. G. Sequence logo plots of the confirmed TNFR2-binding and non-binding CDRL3 sequences for the most frequent CDRL3 length.

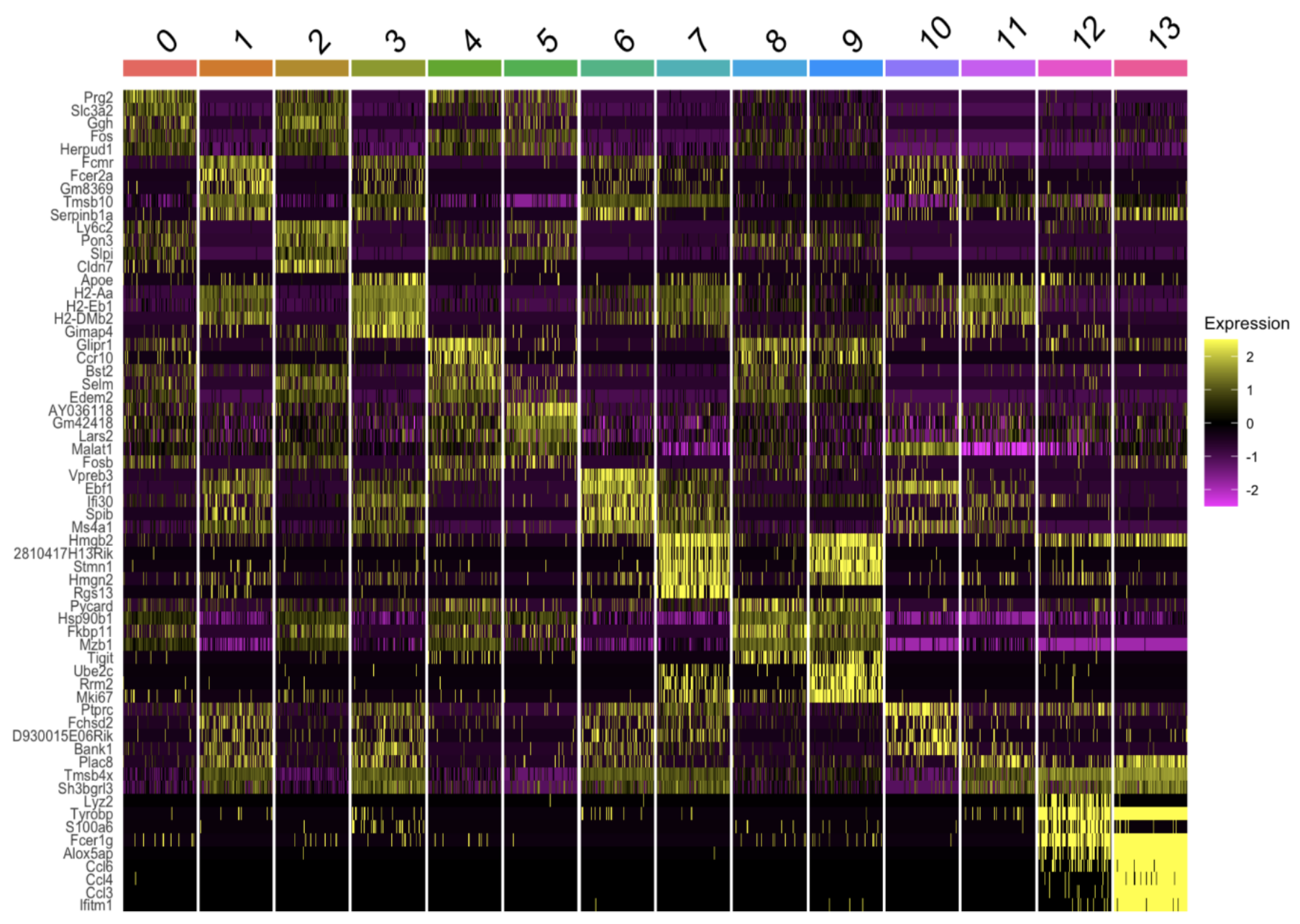


bioRxiv preprint doi: https://doi.org/10.1101/2021.11.09.467876; this version posted November 11,2021 . The copyright holder for this preprint (which was not certified by peer review) is the author/funder, who has granted bioRxiv a license to display the preprint in perpetuity. It is made available under aCC-BY-ND 4.0 International license.

Agrafiotis et al. 32

Figure S9. Top differentially expressed genes for each transcriptional cluster for all repertoires. Heatmap intensity corresponds to normalized expression. Each column represents a single cell and each row corresponds to a single gene. The top five genes based on average log fold change (avg_log2FC) have been selected for each cluster after removing those ribosomal protein $L(R P L)$, ribosomal protein $S$ (RPS), and mitochondrial genes. All displayed genes had an adjusted $p$ value less than or equal to 0.01 .

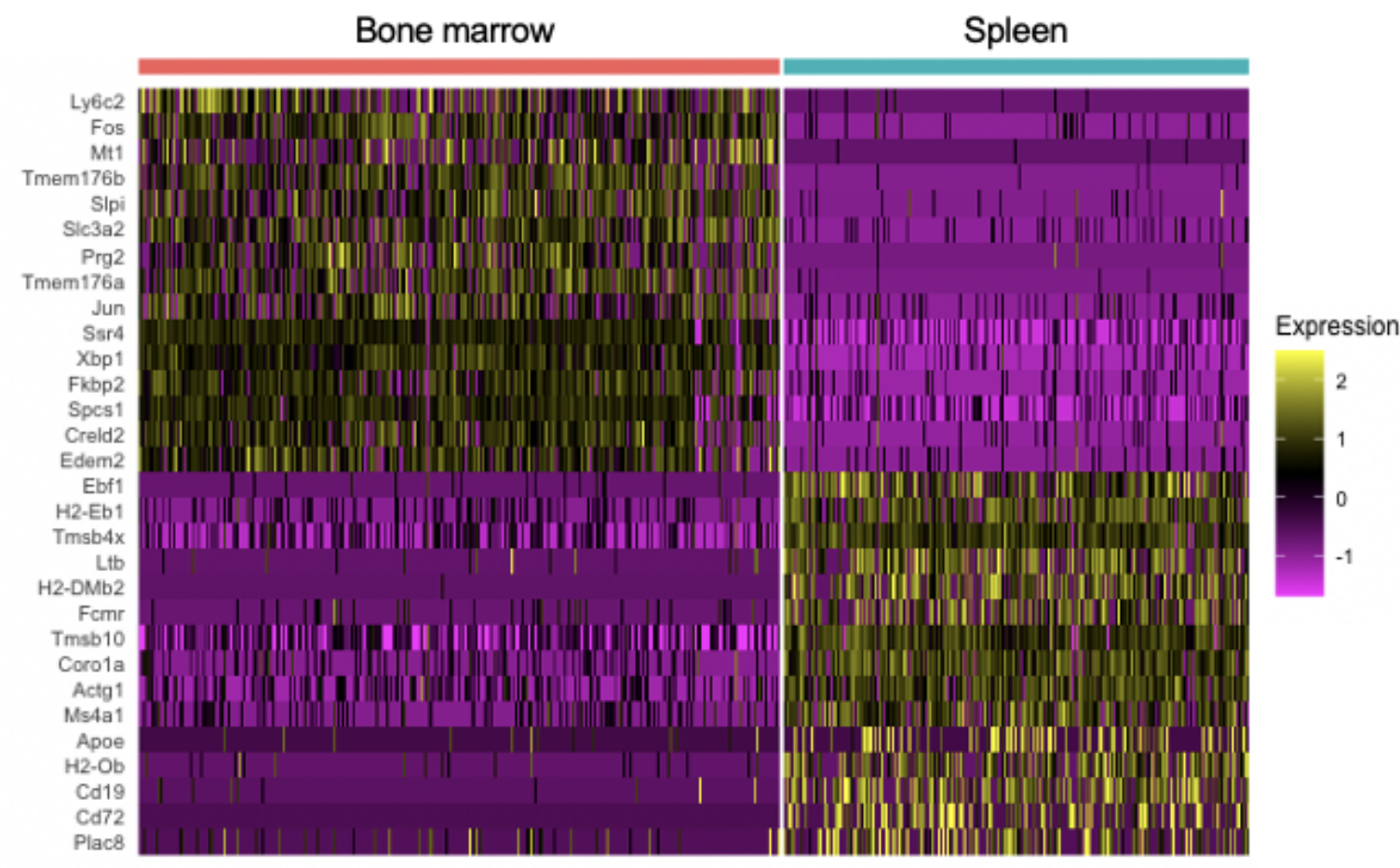

Figure S10. Differentially expressed genes between bone marrow plasma cells and splenic B cells following TNFR2 immunization. The order of genes (from top to bottom) corresponds to the highest average log fold change. All genes displayed have adjusted $p$ values $<0.01$. 
Agrafiotis et al. 33
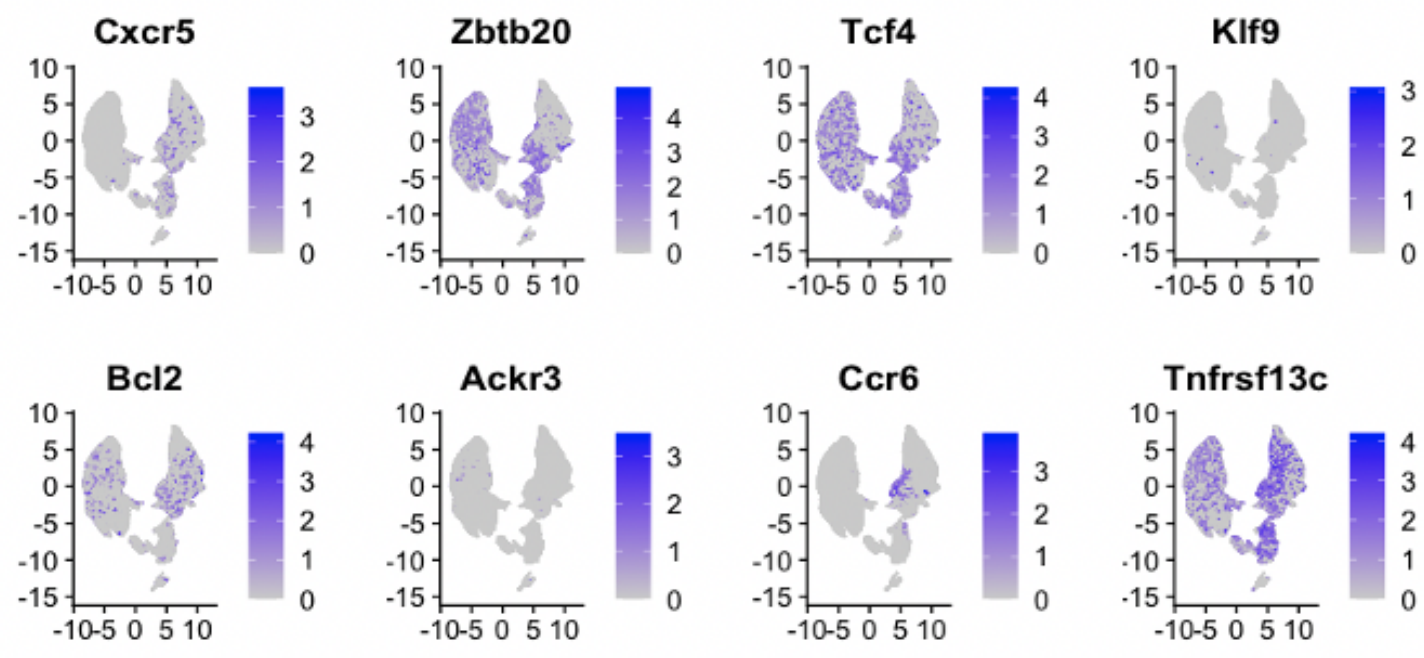

Tnfrsf13c
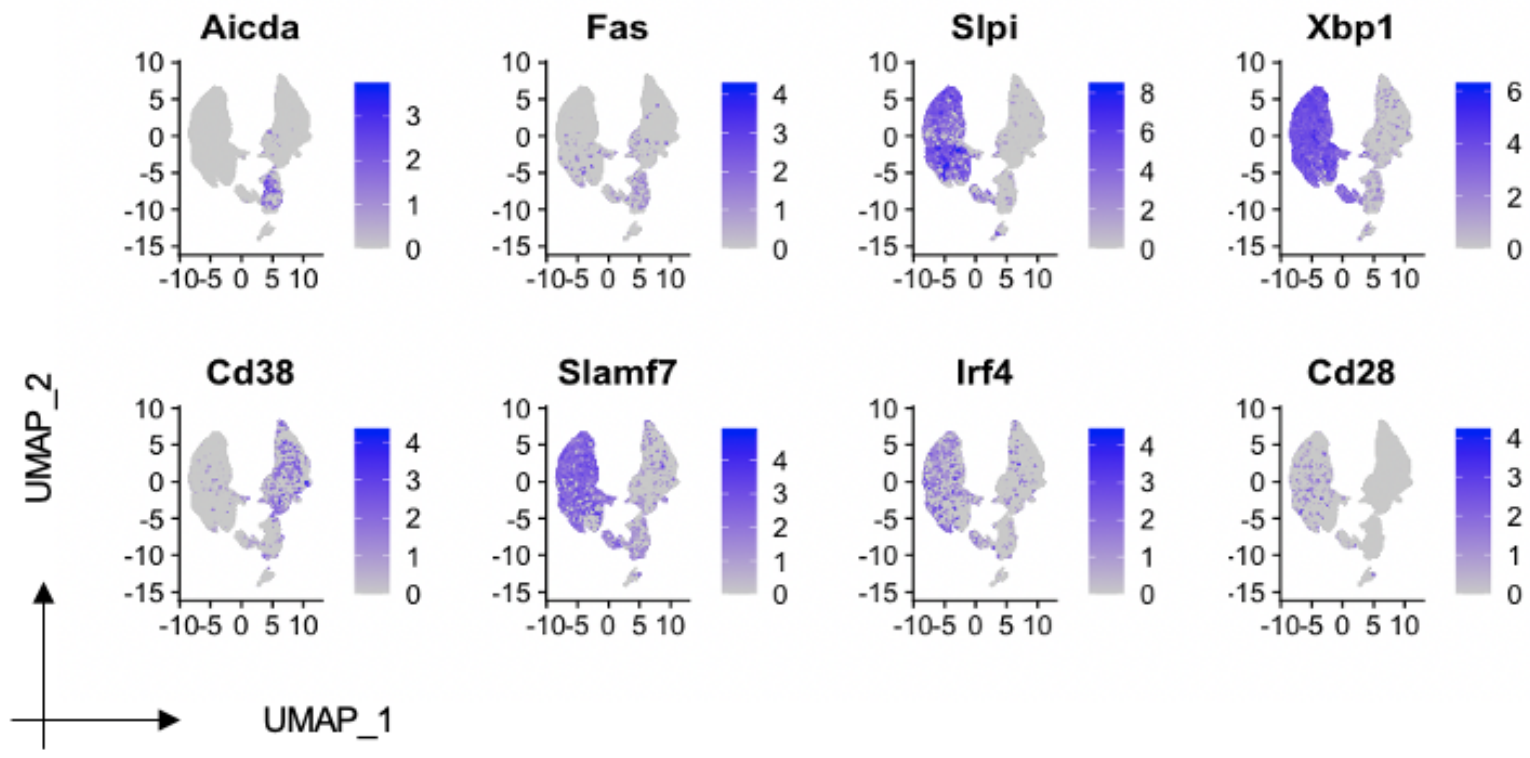

Figure S11. Uniform manifold approximation projection (UMAP) plots showing gene expression for selected genes. 
bioRxiv preprint doi: https://doi.org/10.1101/2021.11.09.467876; this version posted November 11, 2021. The copyright holder for this preprint (which was not certified by peer review) is the author/funder, who has granted bioRxiv a license to display the preprint in perpetuity. It is made available under aCC-BY-ND 4.0 International license.

Agrafiotis et al. 34

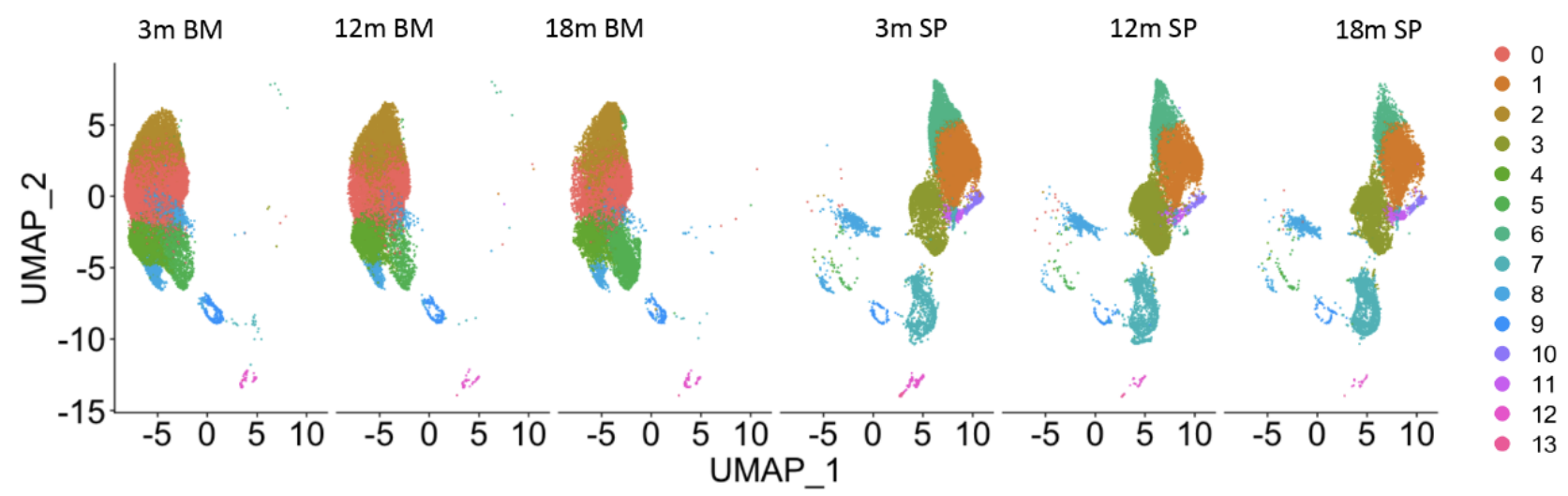

Figure S12. Uniform manifold approximation projection (UMAP) split by age and organ cohort. Each point corresponds to a cell and color corresponds to the transcriptional cluster. 
Agrafiotis et al. 35
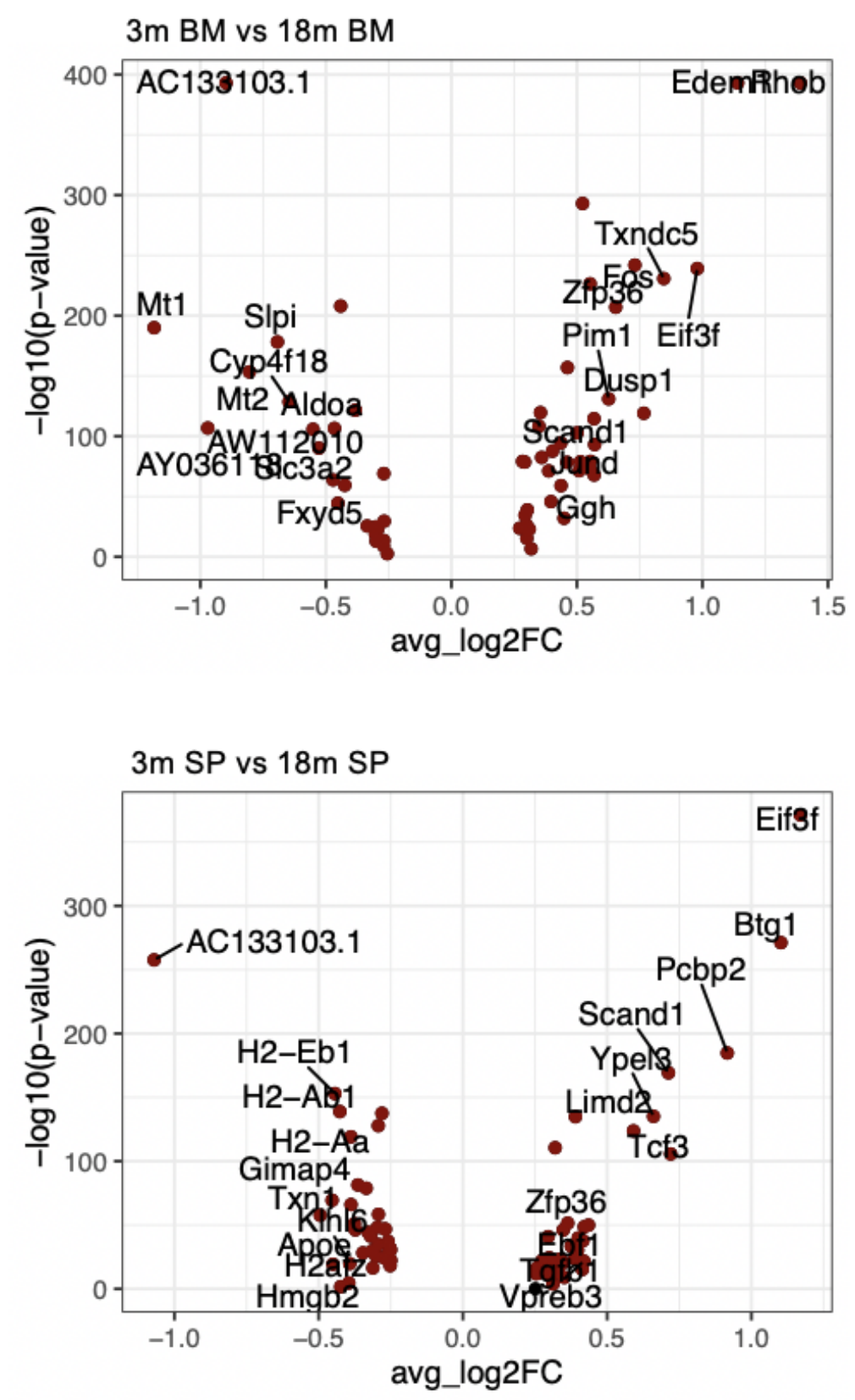

Figure S13. Differential gene expression between young and old separated by organ. Points in red indicate significantly differentially expressed genes $(p$-adj $<0.01)$. 
Agrafiotis et al. 36

\section{Bone marrow}

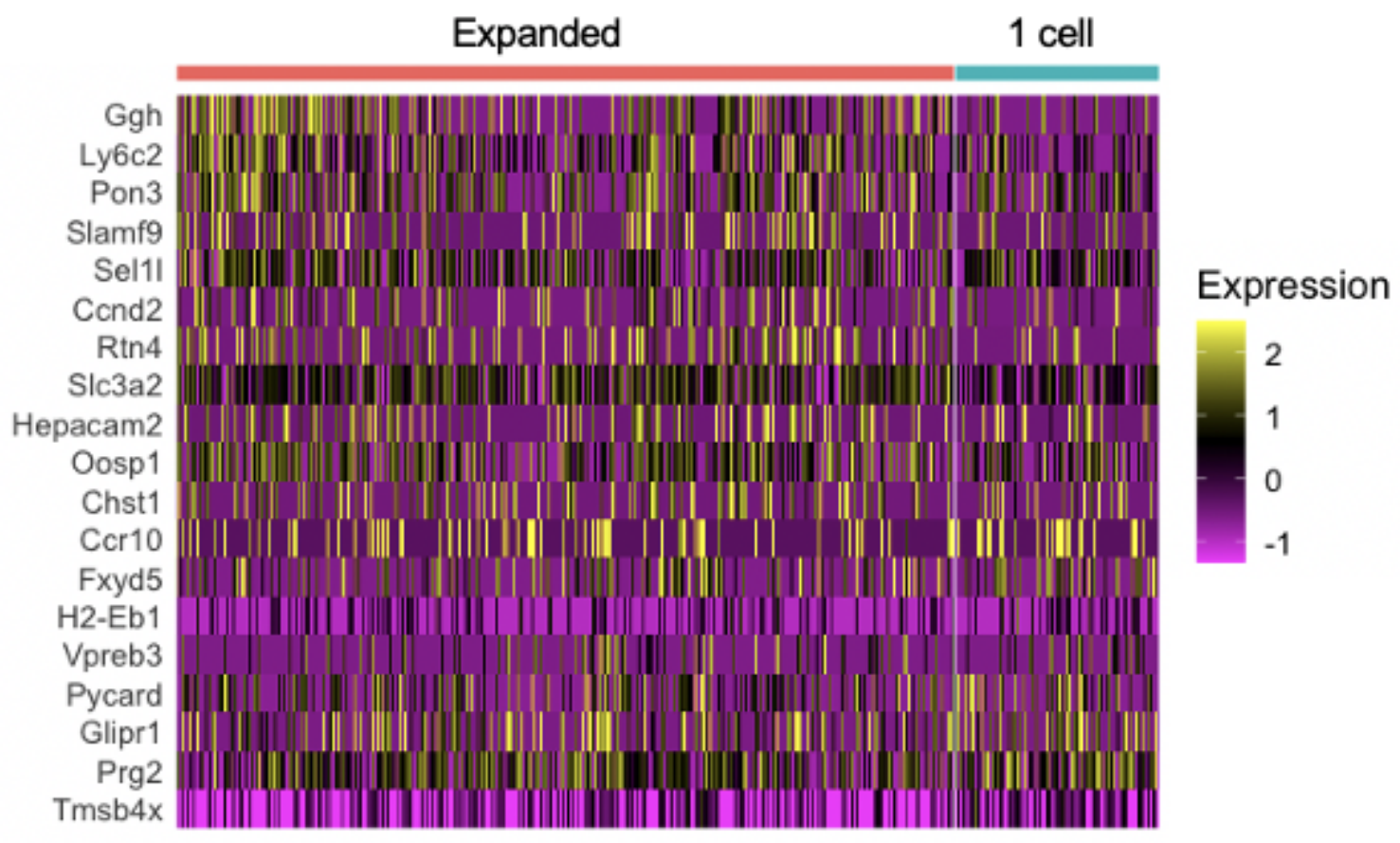

Figure S14. Differentially expressed genes between expanded and unexpanded bone marrow plasma B cells following TNFR2 immunization. The order of genes (from top to bottom) corresponds to the highest average log fold change. All genes displayed have adjusted $p$ values $<0.01$ 
bioRxiv preprint doi: https://doi.org/10.1101/2021.11.09.467876; this version posted November 11,2021 . The copyright holder for this preprint (which was not certified by peer review) is the author/funder, who has granted bioRxiv a license to display the preprint in perpetuity. It is made available under aCC-BY-ND 4.0 International license.

Agrafiotis et al. 37

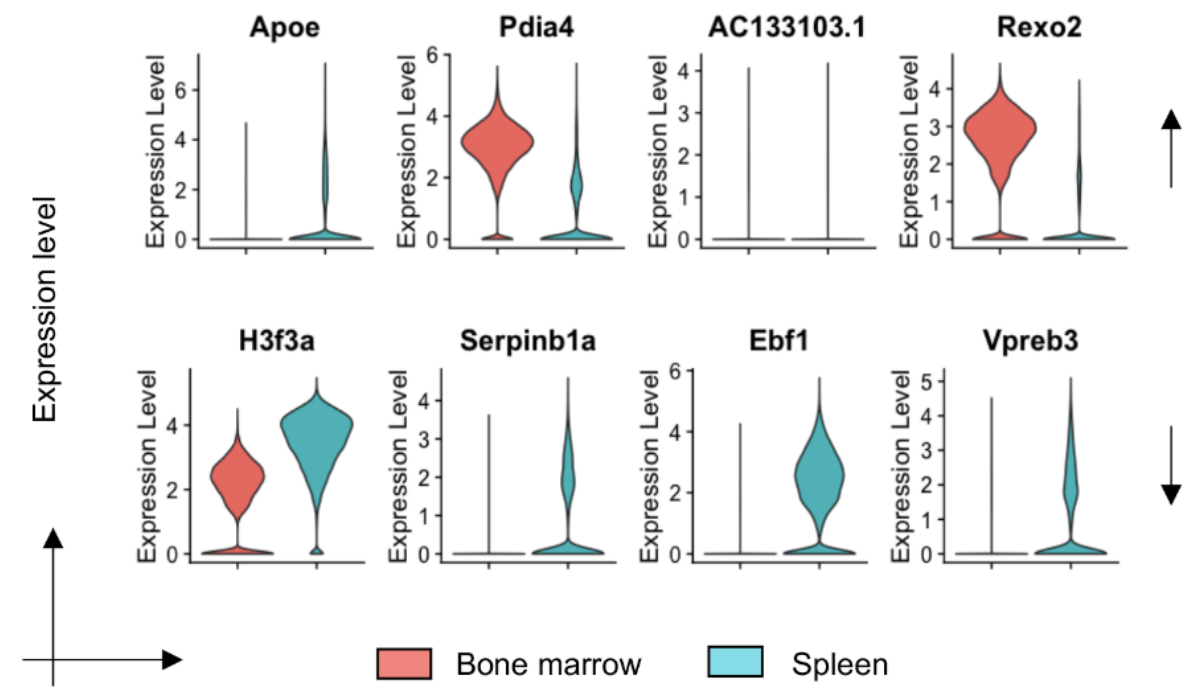

Figure S15. Expression levels of up/down regulated genes from overlapping splenic clones across organs as described in Figure 6B. 
bioRxiv preprint doi: https://doi.org/10.1101/2021.11.09.467876; this version posted November 11,2021 . The copyright holder for this preprint (which was not certified by peer review) is the author/funder, who has granted bioRxiv a license to display the preprint in perpetuity. It is made available under aCC-BY-ND 4.0 International license.

Agrafiotis et al. 38

Binders SP (409 cells) vs Non-binders SP (858 cells)

A

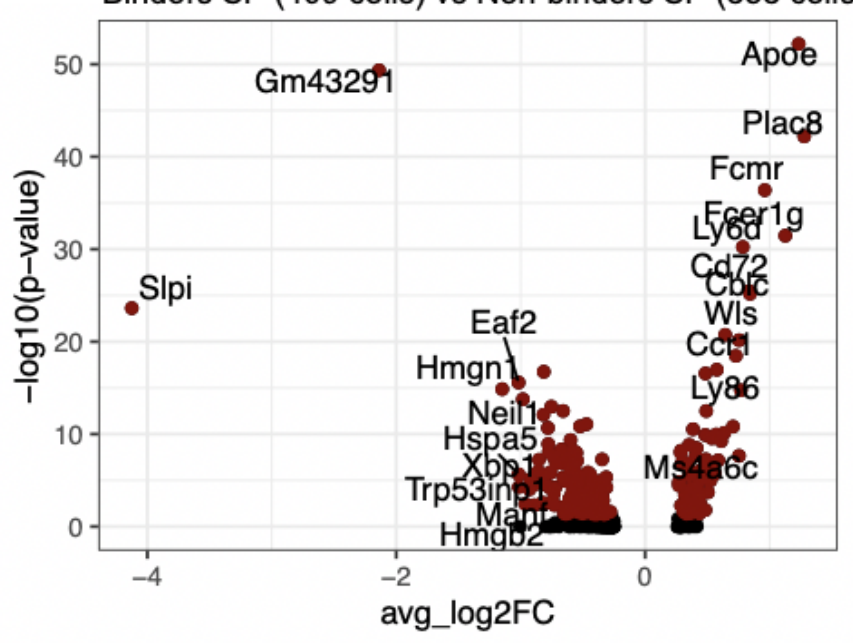

B Binders BM (111 cells) vs Non-binders BM (744 cells)

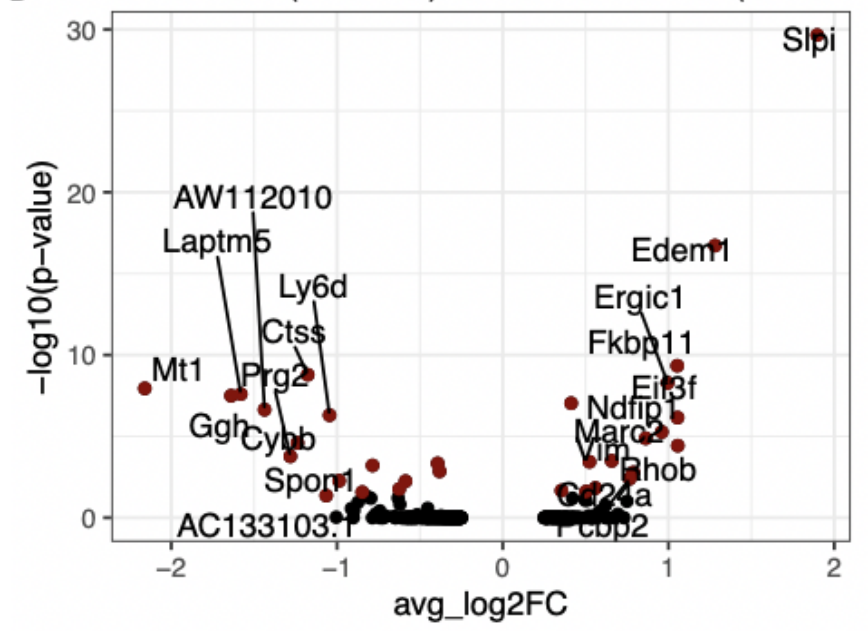

C Binders SP ( 8 cells) vs Non-binders SP (516 cells)

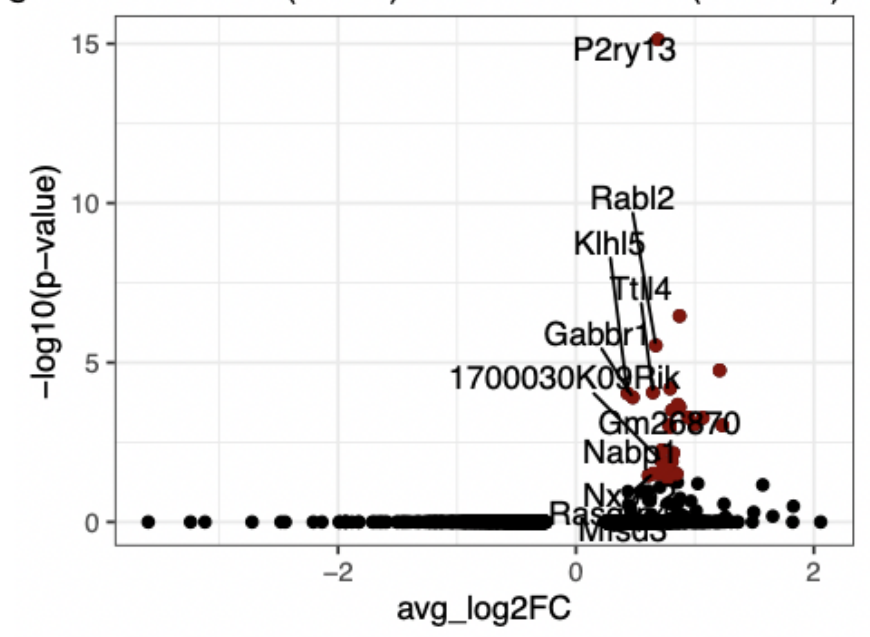

Figure S16. Differentially expressed genes between TNFR2-specific and -unspecific B cells. A. Differential gene expression analysis for binder and non-binder cells from the spleen (SP). B \& C. Differential gene expression analysis for binder and non-binder cells from the $(\mathrm{B})$ bone marrow $(\mathrm{BM})$ and $(\mathrm{C})$ spleen using a more stringent threshold for classifying TNFR2-specificity ( $<2$ and $>10$ fold signal relative to background). 


\section{References}

Allan, L.L., Hoefl, K., Zheng, D.-J., Chung, B.K., Kozak, F.K., Tan, R., and van den Elzen, P. (2009).

Apolipoprotein-mediated lipid antigen presentation in B cells provides a pathway for innate help by NKT cells. Blood 114, 2411-2416.

Andreani, V., Ramamoorthy, S., Pandey, A., Lupar, E., Nutt, S.L., Lämmermann, T., and Grosschedl, R. (2018). Cochaperone Mzb1 is a key effector of Blimp1 in plasma cell differentiation and $\beta 1$-integrin function. Proc. Natl. Acad. Sci. U. S. A. 115, E9630-E9639.

Bailey, J.R., Flyak, A.I., Cohen, V.J., Li, H., Wasilewski, L.N., Snider, A.E., Wang, S., Learn, G.H., Kose, N., Loerinc, L., et al. (2017). Broadly neutralizing antibodies with few somatic mutations and hepatitis $\mathrm{C}$ virus clearance. JCI Insight 2.

Birjandi, S.Z., Ippolito, J.A., Ramadorai, A.K., and Witte, P.L. (2011). Alterations in marginal zone macrophages and marginal zone B cells in old mice. J. Immunol. 186, 3441-3451.

Burton, D.R., and Hangartner, L. (2016). Broadly Neutralizing Antibodies to HIV and Their Role in Vaccine Design. Annu. Rev. Immunol. 34, 635-659.

Cao, Y., Su, B., Guo, X., Sun, W., Deng, Y., Bao, L., Zhu, Q., Zhang, X., Zheng, Y., Geng, C., et al. (2020). Potent Neutralizing Antibodies against SARS-CoV-2 Identified by High-Throughput Single-Cell Sequencing of Convalescent Patients' B Cells. Cell 182, 73-84.e16.

Chevrier, S., Emslie, D., Shi, W., Kratina, T., Wellard, C., Karnowski, A., Erikci, E., Smyth, G.K., Chowdhury, K., Tarlinton, D., et al. (2014). The BTB-ZF transcription factor Zbtb20 is driven by Irf4 to promote plasma cell differentiation and longevity. Journal of Experimental Medicine 211, 827-840.

Corcoran, L.M., and Nutt, S.L. (2016). Long-Lived Plasma Cells Have a Sweet Tooth. Immunity 45, 3-5.

Croote, D., Darmanis, S., Nadeau, K.C., and Quake, S.R. (2018). High-affinity allergen-specific human antibodies cloned from single IgE B cell transcriptomes. Science 362, 1306-1309.

Csepregi, L., Hoehn, K.B., Neumeier, D., Taft, J.M., Friedensohn, S., Weber, C.R., Kummer, A., Sesterhenn, F., Correia, B.E., and Reddy, S.T. (2021). The Physiological Landscape and Specificity of Antibody Repertoires.

Elkon, K., and Casali, P. (2008). Nature and functions of autoantibodies. Nat. Clin. Pract. Rheumatol. 4, 491498.

Eren, R., Zharhary, D., Abel, L., and Globerson, A. (1988). Age-related changes in the capacity of bone marrow cells to differentiate in thymic organ cultures. Cellular Immunology 112, 449-455.

Fischer, R., Kontermann, R.E., and Pfizenmaier, K. (2020). Selective Targeting of TNF Receptors as a Novel Therapeutic Approach. Front Cell Dev Biol 8, 401.

Frasca, D. (2018). Senescent B cells in aging and age-related diseases: Their role in the regulation of antibody responses. Exp. Gerontol. 107, 55-58.

Frasca, D., Van der Put, E., Riley, R.L., and Blomberg, B.B. (2004). Reduced Ig class switch in aged mice correlates with decreased E47 and activation-induced cytidine deaminase. J. Immunol. 172, 2155-2162. 
bioRxiv preprint doi: https://doi.org/10.1101/2021.11.09.467876; this version posted November 11,2021 . The copyright holder for this preprint (which was not certified by peer review) is the author/funder, who has granted bioRxiv a license to display the preprint in perpetuity. It is made available under aCC-BY-ND 4.0 International license.

Agrafiotis et al. 40

Gibson, K.L., Wu, Y.-C., Barnett, Y., Duggan, O., Vaughan, R., Kondeatis, E., Nilsson, B.-O., Wikby, A., Kipling, D., and Dunn-Walters, D.K. (2009). B-cell diversity decreases in old age and is correlated with poor health status. Aging Cell 8, 18-25.

Ginaldi, L., Loreto, M.F., Corsi, M.P., Modesti, M., and De Martinis, M. (2001). Immunosenescence and infectious diseases. Microbes Infect. 3, 851-857.

Goldstein, L.D., Chen, Y.-J.J., Wu, J., Chaudhuri, S., Hsiao, Y.-C., Schneider, K., Hoi, K.H., Lin, Z., Guerrero, S., Jaiswal, B.S., et al. (2019). Massively parallel single-cell B-cell receptor sequencing enables rapid discovery of diverse antigen-reactive antibodies. Communications Biology 2, 1-10.

Goodwin, K., Viboud, C., and Simonsen, L. (2006). Antibody response to influenza vaccination in the elderly: a quantitative review. Vaccine 24, 1159-1169.

Hao, Y., O’Neill, P., Naradikian, M.S., Scholz, J.L., and Cancro, M.P. (2011). A B-cell subset uniquely responsive to innate stimuli accumulates in aged mice. Blood 118, 1294-1304.

Henry, C., Zheng, N.-Y., Huang, M., Cabanov, A., Rojas, K.T., Kaur, K., Andrews, S.F., Palm, A.-K.E., Chen, Y.-Q., Li, Y., et al. (2019). Influenza Virus Vaccination Elicits Poorly Adapted B Cell Responses in Elderly Individuals. Cell Host Microbe 25, 357-366.e6.

Horns, F., Dekker, C.L., and Quake, S.R. (2020). Memory B Cell Activation, Broad Anti-influenza Antibodies, and Bystander Activation Revealed by Single-Cell Transcriptomics. Cell Rep. 30, 905-913.e6.

Jackson, K.J.L., Liu, Y., Roskin, K.M., Glanville, J., Hoh, R.A., Seo, K., Marshall, E.L., Gurley, T.C., Moody, M.A., Haynes, B.F., et al. (2014). Human responses to influenza vaccination show seroconversion signatures and convergent antibody rearrangements. Cell Host Microbe 16, 105-114.

Johnson, S.A., and Cambier, J.C. (2004). Ageing, autoimmunity and arthritis: senescence of the B cell compartment - implications for humoral immunity. Arthritis Res. Ther. 6, 131-139.

Johnson, S.A., Rozzo, S.J., and Cambier, J.C. (2002). Aging-dependent exclusion of antigen-inexperienced cells from the peripheral B cell repertoire. J. Immunol. 168, 5014-5023.

Kline, G.H., Hayden, T.A., and Klinman, N.R. (1999). B cell maintenance in aged mice reflects both increased B cell longevity and decreased B cell generation. J. Immunol. 162, 3342-3349.

Kräutler, N.J., Yermanos, A., Pedrioli, A., Welten, S.P.M., Lorgé, D., Greczmiel, U., Bartsch, I., Scheuermann, J., Kiefer, J.D., Eyer, K., et al. (2020). Quantitative and Qualitative Analysis of Humoral Immunity Reveals Continued and Personalized Evolution in Chronic Viral Infection. Cell Rep. 30, 997-1012.e6.

Kuhn, R., Sandu, I., Agrafiotis, A., Huang, K.-L., Neumeier, D., Merkler, D., Oxenius, A., Reddy, S.T., and Yermanos, A. (2021). Clonally expanded virus-specific CD8 T cells acquire diverse transcriptional phenotypes during acute, chronic, and latent infections.

Kurupati, R.K., Haut, L.H., Schmader, K.E., and Ertl, H.C. (2019). Age-related changes in B cell metabolism. Aging 11, 4367-4381.

Leng, J., and Goldstein, D.R. (2010). Impact of aging on viral infections. Microbes Infect. 12, 1120-1124.

Marchione, R., Leibovitch, S.A., and Lenormand, J.-L. (2013). The translational factor elF3f: the ambivalent elF3 subunit. Cellular and Molecular Life Sciences 70, 3603-3616.

Medler, J., and Wajant, H. (2019). Tumor necrosis factor receptor-2 (TNFR2): an overview of an emerging drug target. Expert Opinion on Therapeutic Targets 23, 295-307. 
Mehr, R., and Melamed, D. (2011). Reversing B cell aging. Aging 3, 438-443.

Agrafiotis et al. 41

Miho, E., Yermanos, A., Weber, C.R., Berger, C.T., Reddy, S.T., and Greiff, V. (2018). Computational Strategies for Dissecting the High-Dimensional Complexity of Adaptive Immune Repertoires. Front. Immunol. 9, 224.

Miller, J.P., and Allman, D. (2003). The decline in B lymphopoiesis in aged mice reflects loss of very early Blineage precursors. J. Immunol. 171, 2326-2330.

Min, H., Montecino-Rodriguez, E., and Dorshkind, K. (2006). Effects of aging on the common lymphoid progenitor to pro-B cell transition. J. Immunol. 176, 1007-1012.

Nechanitzky, R., Akbas, D., Scherer, S., Györy, I., Hoyler, T., Ramamoorthy, S., Diefenbach, A., and Grosschedl, R. (2013). Transcription factor EBF1 is essential for the maintenance of B cell identity and prevention of alternative fates in committed cells. Nat. Immunol. 14, 867-875.

Neumeier, D., Pedrioli, A., Genovese, A., Sandu, I., Ehling, R., Hong, K.-L., Papadopoulou, C., Agrafiotis, A., Kuhn, R., Robbiani, D., et al. (2021a). Single-cell sequencing reveals clonally expanded plasma cells during chronic viral infection produce virus-specific and cross-reactive antibodies.

Neumeier, D., Yermanos, A., Agrafiotis, A., Csepregi, L., Chowdhury, T., Ehling, R.A., Kuhn, R., Roberto, R.B.D., Di Tacchio, M., Antonialli, R., et al. (2021b). Phenotypic determinism and stochasticity in antibody repertoires of clonally expanded plasma cells.

Oh, S.-J., Lee, J.K., and Shin, O.S. (2019). Aging and the Immune System: the Impact of Immunosenescence on Viral Infection, Immunity and Vaccine Immunogenicity. Immune Netw. 19, e37.

Ongrádi, J., and Kövesdi, V. (2011). Numerical alterations of ageing B lymphocyte subsets. Acta Physiol. Hung. 98, 99-104.

Parola, C., Neumeier, D., Friedensohn, S., Csepregi, L., Di Tacchio, M., Mason, D.M., and Reddy, S.T. (2019). Antibody discovery and engineering by enhanced CRISPR-Cas9 integration of variable gene cassette libraries in mammalian cells. MAbs 11, 1367-1380.

Pogson, M., Parola, C., Kelton, W.J., Heuberger, P., and Reddy, S.T. (2016). Immunogenomic engineering of a plug-and-(dis)play hybridoma platform. Nat. Commun. 7, 12535.

Put, E.V. der, Van der Put, E., Frasca, D., King, A.M., Blomberg, B.B., and Riley, R.L. (2004). Decreased E47 in Senescent B Cell Precursors Is Stage Specific and Regulated Posttranslationally by Protein Turnover. The Journal of Immunology 173, 818-827.

Rasmussen, K.L., Tybjærg-Hansen, A., Nordestgaard, B.G., and Frikke-Schmidt, R. (2019). Plasma levels of apolipoprotein E, APOE genotype, and all-cause and cause-specific mortality in 105949 individuals from a white general population cohort. Eur. Heart J. 40, 2813-2824.

Ratliff, M., Alter, S., Frasca, D., Blomberg, B.B., and Riley, R.L. (2013). In senescence, age-associated B cells secrete TNFa and inhibit survival of B-cell precursors. Aging Cell 12, 303-311.

Reimer, D., Lee, A.Y.S., Bannan, J., Fromm, P., Kara, E.E., Comerford, I., McColl, S., Wiede, F., Mielenz, D., and Körner, H. (2017). Early CCR6 expression on B cells modulates germinal centre kinetics and efficient antibody responses. Immunology \& Cell Biology 95, 33-41.

Rodig, S.J., Kutok, J.L., Paterson, J.C., Nitta, H., Zhang, W., Chapuy, B., Tumwine, L.K., Montes-Moreno, S., Agostinelli, C., Johnson, N.A., et al. (2010). The pre-B-cell receptor associated protein VpreB3 is a useful diagnostic marker for identifying c-MYC translocated lymphomas. Haematologica 95, 2056-2062. 
Rodriguez-Zhurbenko, N., Quach, T.D., Hopkins, T.J., Rothstein, T.L., and Hernandez, A.M. (2019). Human B1 Cells and B-1 Cell Antibodies Change With Advancing Age. Front. Immunol. 10, 483.

Rosnet, O., Blanco-Betancourt, C., Grivel, K., Richter, K., and Schiff, C. (2004). Binding of free immunoglobulin light chains to VpreB3 inhibits their maturation and secretion in chicken B cells. J. Biol. Chem. 279, 10228-10236.

Rossi, D.J., Bryder, D., Zahn, J.M., Ahlenius, H., Sonu, R., Wagers, A.J., and Weissman, I.L. (2005). Cell intrinsic alterations underlie hematopoietic stem cell aging. Proc. Natl. Acad. Sci. U. S. A. 102, 9194-9199.

Rubtsov, A.V., Rubtsova, K., Fischer, A., Meehan, R.T., Gillis, J.Z., Kappler, J.W., and Marrack, P. (2011). Tolllike receptor 7 (TLR7)--driven accumulation of a novel CD11c+B-cell population is important for the development of autoimmunity. Blood, The Journal of the American Society of Hematology 118, 1305-1315.

Saikia, M., Burnham, P., Keshavjee, S.H., Wang, M.F.Z., Heyang, M., Moral-Lopez, P., Hinchman, M.M., Danko, C.G., Parker, J.S.L., and De Vlaminck, I. (2019). Simultaneous multiplexed amplicon sequencing and transcriptome profiling in single cells. Nat. Methods 16, 59-62.

Satija, R., Farrell, J.A., Gennert, D., Schier, A.F., and Regev, A. (2015). Spatial reconstruction of single-cell gene expression data. Nat. Biotechnol. 33, 495-502.

Shaffer, A.L., Shapiro-Shelef, M., Iwakoshi, N.N., Lee, A.-H., Qian, S.-B., Zhao, H., Yu, X., Yang, L., Tan, B.K., Rosenwald, A., et al. (2004). XBP1, Downstream of Blimp-1, Expands the Secretory Apparatus and Other Organelles, and Increases Protein Synthesis in Plasma Cell Differentiation. Immunity 21, 81-93.

Shahaf, G., Johnson, K., and Mehr, R. (2006). B cell development in aging mice: lessons from mathematical modeling. Int. Immunol. 18, 31-39.

Shi, J., Kahle, A., Hershey, J.W.B., Honchak, B.M., Warneke, J.A., Leong, S.P.L., and Nelson, M.A. (2006). Decreased expression of eukaryotic initiation factor $3 f$ deregulates translation and apoptosis in tumor cells. Oncogene 25, 4923-4936.

Siegrist, C.-A., and Aspinall, R. (2009). B-cell responses to vaccination at the extremes of age. Nat. Rev. Immunol. 9, 185-194.

Singh, M., Al-Eryani, G., Carswell, S., Ferguson, J.M., Blackburn, J., Barton, K., Roden, D., Luciani, F., Giang Phan, T., Junankar, S., et al. (2019). High-throughput targeted long-read single cell sequencing reveals the clonal and transcriptional landscape of lymphocytes. Nat. Commun. 10, 3120.

Stephan, R.P., Sanders, V.M., and Witte, P.L. (1996). Stage-specific alterations in murine B lymphopoiesis with age. Int. Immunol. 8, 509-518.

Todd, D.J., McHeyzer-Williams, L.J., Kowal, C., Lee, A.-H., Volpe, B.T., Diamond, B., McHeyzer-Williams, M.G., and Glimcher, L.H. (2009). XBP1 governs late events in plasma cell differentiation and is not required for antigen-specific memory B cell development. The Journal of Cell Biology 186, i13-i13.

Trück, J., Ramasamy, M.N., Galson, J.D., Rance, R., Parkhill, J., Lunter, G., Pollard, A.J., and Kelly, D.F. (2015). Identification of antigen-specific B cell receptor sequences using public repertoire analysis. J. Immunol. 194, 252-261.

Turner, J.S., Zhou, J.Q., Han, J., Schmitz, A.J., Rizk, A.A., Alsoussi, W.B., Lei, T., Amor, M., Mclntire, K.M., Meade, P., et al. (2020). Human germinal centres engage memory and naive B cells after influenza vaccination. Nature 586, 127-132.

Vazquez-Lombardi, R., Nevoltris, D., Luthra, A., Schofield, P., Zimmermann, C., and Christ, D. (2018). 
Transient expression of human antibodies in mammalian cells. Nat. Protoc. 13, 99-117.

Agrafiotis et al. 43

Watad, A., Bragazzi, N.L., Adawi, M., Amital, H., Toubi, E., Porat, B.-S., and Shoenfeld, Y. (2017).

Autoimmunity in the Elderly: Insights from Basic Science and Clinics - A Mini-Review. Gerontology 63, 515523.

Weinberger, B., Herndler-Brandstetter, D., Schwanninger, A., Weiskopf, D., and Grubeck-Loebenstein, B. (2008). Biology of immune responses to vaccines in elderly persons. Clin. Infect. Dis. 46, 1078-1084.

Weksler, M.E. (2000). Changes in the B-cell repertoire with age. Vaccine 18, 1624-1628.

Wen, W., Su, W., Tang, H., Le, W., Zhang, X., Zheng, Y., Liu, X., Xie, L., Li, J., Ye, J., et al. (2020). Immune cell profiling of COVID-19 patients in the recovery stage by single-cell sequencing. Cell Discovery 6, 1-18.

Wiede, F., Fromm, P.D., Comerford, I., Kara, E., Bannan, J., Schuh, W., Ranasinghe, C., Tarlinton, D., Winkler, T., McColl, S.R., et al. (2013). CCR6 is transiently upregulated on B cells after activation and modulates the germinal center reaction in the mouse. Immunology \& Cell Biology 91, 335-339.

Wrammert, J., Smith, K., Miller, J., Langley, W.A., Kokko, K., Larsen, C., Zheng, N.-Y., Mays, I., Garman, L., Helms, C., et al. (2008). Rapid cloning of high-affinity human monoclonal antibodies against influenza virus. Nature 453, 667-671.

Yermanos, A., Neumeier, D., Sandu, I., Borsa, M., Waindok, A.C., Merkler, D., Oxenius, A., and Reddy, S.T. (2021a). Single-cell immune repertoire and transcriptome sequencing reveals that clonally expanded and transcriptionally distinct lymphocytes populate the aged central nervous system in mice. Proceedings of the Royal Society B: Biological Sciences 288, 20202793.

Yermanos, A., Agrafiotis, A., Kuhn, R., Robbiani, D., Yates, J., Papadopoulou, C., Han, J., Sandu, I., Weber, C., Bieberich, F., et al. (2021b). Platypus: an open-access software for integrating lymphocyte single-cell immune repertoires with transcriptomes. NAR Genom Bioinform 3.

Yodoi, J., Hosoda, M., Maeda, Y., Sato, S., Takami, M., and Kawabe, T. (1989). FceR2/CD23: Regulation and Functional Roles in Cell Activation. In Progress in Immunology, (Springer Berlin Heidelberg), pp. 724-731.

Zheng, B., Han, S., Takahashi, Y., and Kelsoe, G. (1997). Immunosenescence and germinal center reaction. Immunol. Rev. 160, 63-77. 